\title{
Effect of magnesium on calcium silicate hydrate (C-S-H)
}

Ellina Bernard ${ }^{1)}$, Barbara Lothenbach ${ }^{1)}$, Fabien Le Goff ${ }^{1)}$, Isabelle Pochard ${ }^{2)}$ Alexandre Dauzères ${ }^{3)}$

${ }^{1)}$ Empa, Laboratory for Concrete \& Construction Chemistry, 8600 Dübendorf, Switzerland

${ }^{2)}$ Université Bourgogne-Franche-Comté, 21078 Dijon, France

3) IRSN, Institute of Radiation Protection and Nuclear Safety, PRP-DGE/SRT/LETIS, BP 17, 92262 Fontenay aux Roses, France

Corresponding author: Bernard Ellina, email: ellina.bernard@empa.ch

\section{Abstract}

The addition of $\mathrm{MgCl}_{2}$ to synthetic calcium silicate hydrate $(\mathrm{C}-\mathrm{S}-\mathrm{H})$ with $\mathrm{Ca} / \mathrm{Si}=0.8$ lowers the $\mathrm{pH}$ values below 10. Experimental observations and thermodynamic calculations show the destabilization of C-S-H and the precipitation of magnesium silicate hydrate (M-S-H). In contrast, the addition of $\mathrm{MgO}$ to $\mathrm{C}-\mathrm{S}-\mathrm{H}$ increases the $\mathrm{pH}$ values up to 11.5 and the $\mathrm{Ca} / \mathrm{Si}$ in $\mathrm{C}-\mathrm{S}$ $\mathrm{H}$ from 0.8 to $\sim 1.0$. At high $\mathrm{pH}$, the formation of $\mathrm{M}-\mathrm{S}-\mathrm{H}$ and brucite is observed experimentally. Less brucite is present at 50 than at $20^{\circ} \mathrm{C}$ indicating a slow dissolution kinetic of brucite at $20^{\circ} \mathrm{C}$. Thermodynamic modelling is in good agreement with the changes in C-S-H and M-S-H formation in the presence of $\mathrm{MgO}$ although no brucite is predicted.

M-S-H is observed in the presence of both $\mathrm{MgCl}_{2}$ and $\mathrm{MgO}$, is stable from $\mathrm{pH} 7.5$ to 11.5 and has a structure comparable to the structure of $\mathrm{M}-\mathrm{S}-\mathrm{H}$ prepared from $\mathrm{MgO}$ and $\mathrm{SiO}_{2}$ only.

\section{Keywords}

Low-pH cement, C-S-H, M-S-H, ${ }^{29}$ Si MAS NMR, thermodynamic modelling 


\section{Introduction}

The possible future disposal of radioactive wastes in deep repository will create interfaces between cementitious materials and clay-rich rocks. In these contact areas the differences in $\mathrm{pH}$ and alkali, calcium and magnesium concentrations in the pore solution will result in a transition zone [1-3]. "Low-pH concretes" have been developed to reduce the alkalinity of the cement and the $\mathrm{pH}$ of the solution diffusing into the clayey rocks, [4-6].

Decalcification of calcium silicate hydrate (C-S-H), leaching and carbonation have been observed in the hydrated cement paste at the interaction zone with the clayey rocks; all these phenomena decrease the $\mathrm{pH}$ at the hydrated cement paste/clay interface and lead to the formation of silica gel in the case of "low $\mathrm{pH}$ cements" $[1,7,8]$. In the interstitial solution of the clay, relatively high magnesium concentration $(3-40 \mathrm{mmol} / \mathrm{L})$ is present $[1,2,8]$. Magnesium reacts with silica from the cement leading, under water saturated conditions, to the formation of M-S-H (magnesium silicate hydrate) $[1,7]$ along with possible hydrotalcite $[7,8]$.

Studies on the formation of synthetic M-S-H from $\mathrm{SiO}_{2}$ and $\mathrm{MgO}$ show that the rate of $\mathrm{M}-\mathrm{S}-\mathrm{H}$ formation is very slow [9-12]. Initially, brucite, $\mathrm{Mg}(\mathrm{OH})_{2}$, forms from $\mathrm{MgO}$ and reacts slowly with amorphous silica. A "transitional M-S-H" [11] is formed initially with a $\mathrm{Mg} / \mathrm{Si}$ of $0.8-1.0$ independent of the total $\mathrm{Mg} / \mathrm{Si}$ [9-14]. Only after longer equilibration times, the $\mathrm{M}-\mathrm{S}-\mathrm{H}$ composition varies with the initial $\mathrm{Mg} / \mathrm{Si}$ with a range observed between 0.8 and $1.3[11,15,16]$. $\mathrm{M}-\mathrm{S}-\mathrm{H}$ is stable at $\mathrm{pH}$ values between 8 to $10.4[11,12,15]$.

Portlandite and high $\mathrm{Ca} / \mathrm{Si} \mathrm{C}-\mathrm{S}-\mathrm{H}$, the most important hydrates in hydrated Portland cement, are generally observed at $\mathrm{pH} \geq 12.5$. Lower $\mathrm{pH}$ values between 10 to 12.5 are measured for synthetic $\mathrm{C}-\mathrm{S}-\mathrm{H}$ [17-22] and also in "low $\mathrm{pH}$ " cements in the absence of portlandite where a low $\mathrm{Ca} / \mathrm{Si}$ C-S-H (0.7-1.3) is present [4-6]. 
The C-S-H solid composition is well investigated and depends mainly on the total $\mathrm{Ca} / \mathrm{Si}$ and the $\mathrm{pH}[20,23-26]$. C-S-H consists of calcium oxide layers each sandwiched on both side by silicate chains with the typical dreierketten structure [24]; i.e. with repeating building blocks consisting of two pairing silicate tetrahedra attached to the calcium oxide layer and a bridging position, which can be occupied by a bridging silicate tetrahedra or be empty, depending on the C-S-H composition. Thus, silicate in C-S-H, investigated by ${ }^{29} \mathrm{Si}$ MAS NMR, is either bound to one silicate neighbor $\left(\mathrm{Q}^{1}\right)$ at high $\mathrm{Ca} / \mathrm{Si}$ or to two neighbors, $\mathrm{Q}^{2}$ at low $\mathrm{Ca} / \mathrm{Si}$ ratio. In contrast, $\mathrm{M}-\mathrm{S}-\mathrm{H}$ gels have a layered silicate structure $[13,15,16,27,28]$, similar as in clay minerals, and silicate is bound to two or three neighbors $\left(\mathrm{Q}^{2}\right.$ and $\left.\mathrm{Q}^{3}\right)$.

It has been suggested that magnesium could be incorporated in calcium silicate hydrate [29-31], although no clear experimental evidence was presented. Very limited Mg-Ca exchange could have occurred at the surface of tobermorite (natural mineral with a structure, stoichiometry and density similar to a low $\mathrm{Ca} / \mathrm{Si} \mathrm{C}-\mathrm{S}-\mathrm{H})[32,33]$ while for natural samples of tobermorite rather the presence of tobermorite with $\mathrm{M}-\mathrm{S}-\mathrm{H}$ and calcite in small veins have been observed [34]. According to Lothenbach et al. [35], the existence of different silicate structure, as described above, prevents the formation of a "M-C-S-H" phase but leads to the presence of separate M-S-H and $\mathrm{C}-\mathrm{S}-\mathrm{H}$ phases in a mix containing both $\mathrm{Mg}$ and $\mathrm{Ca}$. However, a small uptake of magnesium in $\mathrm{C}-\mathrm{S}-\mathrm{H}$ and vice versa cannot be excluded. The presence of two solids confirms the conclusions of Brew and Glasser [13] that magnesium calcium silicate hydrate are not stable.

In the present paper, the effect of magnesium on the stability of C-S-H has been investigated by batch experiments where magnesium oxide or magnesium chloride were added to $\mathrm{C}-\mathrm{S}-\mathrm{H}$ with a $\mathrm{Ca} / \mathrm{Si}$ ratio equal to 0.8 . 


\section{Materials and methods}

\subsection{Synthesis}

The synthesis of the C-S-H suspensions was done in a glovebox under nitrogen gas to minimize $\mathrm{CO}_{2}$ contamination. Calcium oxide and silica fume $\left(\mathrm{SiO}_{2}\right.$, Aerosil $200,0.9$ wt. $\left.\% \mathrm{HCl}\right)$ have been

chosen as starting materials for the $\mathrm{C}-\mathrm{S}-\mathrm{H}$ synthesis. $\mathrm{CaO}$ has been obtained by burning calcium carbonate $\left(\mathrm{CaCO}_{3}\right.$, Merck, pro analysis) for 12 hours at $1000{ }^{\circ} \mathrm{C}$ as detailed in [36]. $4.27 \mathrm{~g}$ of $\mathrm{CaO}$ and $5.73 \mathrm{~g}$ of $\mathrm{SiO}_{2}$ were mixed with $225 \mathrm{ml}$ of MilliQ-water in $250 \mathrm{ml}$ PE-HD containers to obtain C-S-H with a $\mathrm{Ca} / \mathrm{Si}$ of 0.8 . The containers were sealed and stored at $20^{\circ} \mathrm{C}$ on a horizontal shaker $(100 \mathrm{rpm})$ for one month. After one month, the C-S-H suspensions were separated by vacuum filtration using nylon filters $(0.45 \mu \mathrm{m})$ in a glovebox under nitrogen. Directly following the filtration, the wet C-S-H ( $2 \mathrm{~g}$ of C-S-H with additional pure water of approx. $20 \mathrm{ml}$ ) was put in $100 \mathrm{ml}$ PE-HD containers.

$\mathrm{MgCl}_{2}$ (Anhydrous $\geq 98 \%$, Sigma Aldrich) was dissolved in milli-Q water and added to the C-S-H (C-S-H and water) in the containers, resulting a water/solid (W/S) ratio equal to 54 and $\mathrm{Mg} / \mathrm{Si}$ ratios of $0.05,0.11,0.15,0.26,0.87$ and 1.34 .

$\mathrm{MgO}$ (Merk, pro analysis, containing $0.18 \pm 0.02 \mathrm{wt} . \% \mathrm{Na}_{2} \mathrm{O}$ ) was added directly to C-S-H, as the solubility of $\mathrm{MgO}$ in water is low, and $90 \mathrm{ml}$ milli-Q water in the containers to reach W/S equal to 54 and $\mathrm{Mg} / \mathrm{Si}$ of $0.04,0.23,0.59$ and 0.86 .

After the addition of $\mathrm{MgO}$ or $\mathrm{MgCl}_{2}$ to $\mathrm{C}-\mathrm{S}-\mathrm{H}$, the samples were again equilibrated for 3 and 12 months at 20 and $50^{\circ} \mathrm{C}$. Also, pure C-S-H suspension samples have been prepared and analyzed. The suspensions equilibrated at $20^{\circ} \mathrm{C}$ were placed on a horizontal shaker $(100 \mathrm{rpm})$ while the 
suspensions at $50^{\circ} \mathrm{C}$ were shaken weekly by hand. The analysis of the solids in this paper is focused on three samples of each set at $20^{\circ} \mathrm{C}$ after 12 months only as detailed in bold in Table 1 .

Table 1: Starting materials for the theoretical $2 \mathrm{~g}$ of wet $\mathrm{C}-\mathrm{S}-\mathrm{H}$ with $\mathrm{Ca} / \mathrm{Si}=0.80$ and the different additions of $\mathrm{MgCl}_{2}$ to reach the theoretical $\mathrm{Mg} / \mathrm{Si}$ of $0.05 ; 0.26 ; 0.87 ; 1.34$ and the different additions of $\mathrm{MgO}$ to reach the theoretical Mg/Si of 0.04; 0.23; 0.59; 0.86 ( $g$ = grams; $\mathrm{Mg} / \mathrm{Si}=$ molar ratio).

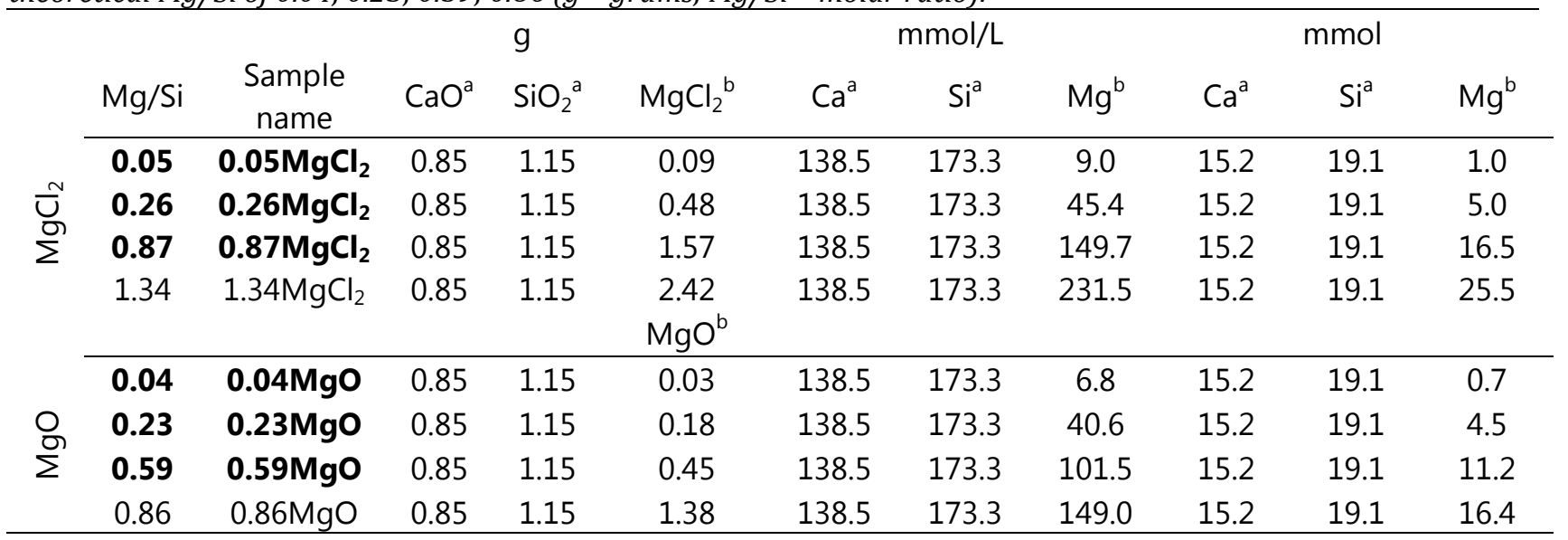

Samples in bold=samples fully analysed

a theoretical values

${ }^{b}$ measured values

After 3 and 12 months the suspensions were separated by vacuum filtration using $0.45 \mu \mathrm{m}$ nylon filters in the glovebox under nitrogen.

Following the filtration, the liquid phases were recovered and the solids were washed with a $50 / 50$ (volume) water-ethanol mix and then with ethanol (94 wt\% alcohol) to remove dissolved ions and to prevent the precipitation of salts during drying. The samples were freeze dried with liquid nitrogen (around $20 \mathrm{~min}$ at $-195^{\circ} \mathrm{C}$ ) and kept at $-40^{\circ} \mathrm{C}$ at $0.28 \mathrm{mbar}$ pressure (vacuum) for a further 7 days. The solid phase analysis were done after further equilibration in $\mathrm{N}_{2}$ filled desiccators over saturated $\mathrm{CaCl}_{2}$ solution for a period of 14 days or longer to ensure $\sim 30 \% \mathrm{RH}$ in all the samples. Before analysis the samples were gently ground by hand. 


\subsection{Analytical techniques}

The composition of the liquid phase was analyzed by ion chromatography (IC) immediately after filtration. The concentrations of $\mathrm{Mg}, \mathrm{Ca}, \mathrm{Na}, \mathrm{Si}, \mathrm{Cl}$, in undiluted solutions or in solutions diluted by factors 10, 100 and 1000 were quantified using a Dionex DP serie ICS-3000 ionic chromatography system. Independent measurements of solution with known compositions indicated a measurement error $\leq 10 \%$. All concentrations have been determined as duplicate and the mean is given. The $\mathrm{pH}$ values $( \pm 0.1)$ were measured at ambient temperature $\left(23 \pm 2{ }^{\circ} \mathrm{C}\right)$ in an aliquot of the unfiltered suspension and the measured $\mathrm{pH}$ values were corrected to 20 or $50{ }^{\circ} \mathrm{C}$. No significant modification in the aqueous phase composition is expected within the 30 minutes used to cool down the solutions from $50{ }^{\circ} \mathrm{C}$ to ambient temperature, as $\mathrm{M}-\mathrm{S}-\mathrm{H}$ precipitation occurs only very slowly and as no significant differences in the concentrations measured by IC between diluted and not-diluted solutions were observed.

Thermogravimetric analyses (TGA) were done on ground powder $(\sim 20-30 \mathrm{mg})$ using a heating rate of $20{ }^{\circ} \mathrm{C} / \mathrm{min}$ from 30 to $980{ }^{\circ} \mathrm{C}$ with a Mettler Toledo TGA/SDTA 8513 instrument. The amount of $\mathrm{Mg}(\mathrm{OH})_{2}$ (brucite) was quantified from the water weight loss around $400-420{ }^{\circ} \mathrm{C}$ using the tangential method [37] and calculated according to the Equation (1):

$$
\text { wt. } \% \text { brucite }_{\text {dry }}=\frac{\text { water loss }(\text { brucite })}{100-\text { water } \operatorname{loss}\left(30-550^{\circ} \mathrm{C}\right)} \times \frac{M_{\text {brucite }}}{M_{\mathrm{H} 2 \mathrm{O}}} \times 100
$$

Where wt. $\%$ brucite $_{\text {dry }}$ corresponds to the wt.\% of brucite for $100 \mathrm{~g}$ of dry mass $(\mathrm{g} / 100 \mathrm{~g})$ and the water losses are in wt. $\%$. $\mathrm{M}_{\text {brucite }}$ is the molar mass of $\mathrm{Mg}(\mathrm{OH})_{2}$, equal to $58.32 \mathrm{~g} / \mathrm{mol}$ and $\mathrm{M}_{\mathrm{H} 2 \mathrm{O}}$ is the molar mass of the water, equal to $18.02 \mathrm{~g} / \mathrm{mol}$. The relative error on the brucite content is $\pm 5-10 \%[37,38]$ 
XRD data were collected using a PANalytical X'Pert Pro MPD diffractometer equipped with rotating sample stage in a theta-2theta configuration applying $\mathrm{CuKa}$ radiation $(\lambda=1.54 \AA)$ at $45 \mathrm{mV}$ voltage and $40 \mathrm{~mA}$ intensity with steps of $0.03^{\circ} 2$ theta and $450.2 \mathrm{~s}$ per step with a fixed divergence slit size and an anti-scattering slit on the incident beam of $0.5^{\circ}$ and $1^{\circ} 2$ theta. The samples were scanned between $5^{\circ}$ and $75^{\circ} 2$ theta with a $X^{\prime}$ Celerator detector.

Attenuated total reflectance (ATR) Fourier Transformation-Infrared (FTIR) spectra were recorded on a Bruker Tensor 27 FT-IR spectrometer by transmittance between 600 and $4000 \mathrm{~cm}^{-1}$ with a resolution of $4 \mathrm{~cm}^{-1}$ on $\sim 3 \mathrm{mg}$ of powder.

The ${ }^{29} \mathrm{Si}$ MAS NMR experiments were recorded on a Bruker Avance III NMR spectrometer using a $7 \mathrm{~mm} \mathrm{CP/MAS} \mathrm{probe} \mathrm{at} 79.5 \mathrm{MHz}$ applying the following parameters: $4500 \mathrm{~Hz}$ sample rotation rate, minimum of 3072 scans or more, $90^{\circ} 1 \mathrm{H}$ pulse of $7.5 \mu \mathrm{s}, 20 \mathrm{~s}$ relaxation delays, $\mathrm{RF}$ field strength of $33.3 \mathrm{kHz}$ during SPINAL64 proton decoupling. The ${ }^{29} \mathrm{Si}$ chemical shifts NMR spectra were referenced to the Aldrich external sample of tetramethylsilane (TMS) with ${ }^{29} \mathrm{Si}$ a chemical shift at $-2.3 \mathrm{ppm}$. The observed ${ }^{29} \mathrm{Si}$ resonances were analysed using the $\mathrm{Q}^{\mathrm{n}}$ classification, where a Si tetrahedron is connected to $\mathrm{n}$ Si tetrahedra with n varying from 0 to 4 . The quantification was performed by non-linear least-square fits using the software "DMFIT" developed by Massiot et al [39]. Silica fume was quantified taking into account the shift at -100.9 ppm $\left((\mathrm{SiO})_{3} \mathrm{Si}-\mathrm{OH}\right.$ from the surface of the amorphous silica $\left.[15,27]\right)$ and the $\mathrm{Q}^{4}$ shift at -110 ppm. However, the relaxation time $T_{1}$ of amorphous silica can be very long and it could be that the amount of silica fume is slightly underestimated.

The deconvolutions of the signals attributed to $\mathrm{C}-\mathrm{S}-\mathrm{H}$ were done following the procedure outlined in [40], with a constant Lorentzian/Gaussian ratio equal to 0.5 and by keeping constant the ratio between bridging and pairing silicate tetrahedra following the Equation (2): 


$$
\frac{Q^{2}{ }_{b}+Q^{2} u}{Q^{2}{ }_{p}}=0.5
$$

Where $\mathrm{Q}^{2}{ }_{\mathrm{b}}$ is the bridging silicate tetrahedra with one calcium neighbor in the interlayer, $\mathrm{Q}^{2}$ is the bridging tetrahedra with one $\mathrm{H}^{+}$neighbor in the interlayer and finally $\mathrm{Q}_{\mathrm{p}}^{2}$ is the pairing tetrahedra. The mean chain length (MCL) of the silicate chains in C-S-H was calculated following the Equation (3):

$$
M C L=\frac{2\left(Q^{1}+Q^{2}{ }_{b}+Q^{2}{ }_{u}+Q^{2}{ }_{p}\right)}{Q^{1}}
$$

M-S-H deconvolutions were done with the The $\mathrm{Q}^{1}$ and $\mathrm{Q}^{2}$ environments were deconvoluted using mainly Lorentzian while the $\mathrm{Q}^{3}$ environment was deconvoluted with Gaussian following the procedure outlined by [11]. Based on the available M-S-H deconvolutions in literature [11, 15, $16,28]$, the $\mathrm{Q}^{2} / \mathrm{Q}^{3}$ ratio was kept between 0.4 [28] and 1 [11].

The Raman spectra were measured with a Bruker Senterra instrument of $5 \mathrm{~cm}^{-1}$ spectral resolution, using a $532 \mathrm{~nm}$ laser $(20 \mathrm{~mW})$ at room temperature and with $\times 50$ objective lens. The spectral acquisition time was $40 \mathrm{~s}$ and 5 spectra were accumulated for each sample in the frequency ranges of $110-1560 \mathrm{~cm}^{-1}$.

After quantification of brucite by TGA, and amorphous silica by ${ }^{29} \mathrm{Si}$ MAS NMR, the composition of the solids was calculated by mass balance including the solution composition based on the IC results. The composition of some solids has been also determined directly by dissolving $20 \mathrm{mg}$ of the solid sample in $10 \mathrm{ml}$ of $0.1 \mathrm{~mol} / 1$ hydrochloric acid. This was repeated 3 times and the mean values are given. 
The pure M-S-H reference samples used for comparison in the present paper were synthetized from $\mathrm{MgO}$ and $\mathrm{SiO}_{2}$ and are fully detailed in [11].

\subsection{Thermodynamic modelling}

Thermodynamic modelling of the experiments was carried out using the Gibbs free energy minimization program GEMS [41]. GEMS software is a broad-purpose geochemical modelling code which computes equilibrium phase assemblage and speciation in a complex chemical system from its total bulk elemental composition. The thermodynamic data for aqueous species as well as for $\mathrm{SiO}_{2}$, brucite and portlandite were taken from the PSI-GEMS thermodynamic database [42], the data for C-S-H (CSHT model) from [43] and the data for the M-S-H were taken from [11]. A summary of the data used is given in Table 2.

Table 2 : Standard thermodynamic properties at $25^{\circ} \mathrm{C}$.

\begin{tabular}{|c|c|c|c|c|c|}
\hline & $*$ & $\log _{S 0}{ }^{a}$ & $\begin{array}{c}\Delta_{\mathrm{f}} \mathrm{G}^{\circ} \\
{[\mathrm{kJ} / \mathrm{mol}]}\end{array}$ & $\begin{array}{c}\mathrm{V}^{\circ} \\
{\left[\mathrm{cm}^{3} / \mathrm{mol}\right]}\end{array}$ & $\begin{array}{l}\text { density } \\
{\left[\mathrm{g} / \mathrm{cm}^{3}\right]}\end{array}$ \\
\hline Brucite [42] & $\mathrm{MH}$ & -11.16 & -832.23 & 24.6 & 2.37 \\
\hline \multicolumn{6}{|l|}{$\boldsymbol{M - S - H}[11]$} \\
\hline $\mathrm{Mg} / \mathrm{Si}=0.78$ & $\mathrm{M}_{0.78} \mathrm{SH}_{1.48}$ & -14.59 & -1682.2 & 57 & $2.1^{\mathrm{b}}$ \\
\hline $\mathrm{Mg} / \mathrm{Si}=1.30$ & $\mathrm{M}_{1.3} \mathrm{SH}_{1.80}$ & -21.44 & -2073.5 & 71 & $2.0^{\mathrm{b}}$ \\
\hline Portlandite [42] & $\mathrm{CH}$ & -5.2 & -897.01 & 33.1 & 2.24 \\
\hline \multicolumn{6}{|l|}{$\boldsymbol{C - S - H}[43]$} \\
\hline $\mathrm{Ca} / \mathrm{Si}=0.67$ & $\mathrm{C}_{0.67} \mathrm{SH}_{1.60}$ & -10.24 & -1707.3 & 56.6 & 2.25 \\
\hline $\mathrm{Ca} / \mathrm{Si}=1.0$ & $\mathrm{C}_{1.00} \mathrm{SH}_{2.00}$ & -13.41 & -2014.5 & 63.4 & 2.4 \\
\hline $\mathrm{Ca} / \mathrm{Si}=1.5$ & $\mathrm{C}_{1.5} \mathrm{SH}_{2.50}$ & -16.61 & -2466.0 & 80.6 & 2.35 \\
\hline $\mathbf{S i O}_{2}, \mathbf{a m}[42]$ & $\mathrm{S}$ & -2.71 & -848.9 & 29 & 2.07 \\
\hline
\end{tabular}

${ }^{*}$ cement short hand notation: $\mathrm{C}=\mathrm{CaO} ; \mathrm{H}=\mathrm{H}_{2} \mathrm{O} ; \mathrm{M}=\mathrm{MgO} ; \mathrm{S}=\mathrm{SiO}_{2}$.

${ }^{a}$ All solubility products refer to the solubility with respect to the species $\mathrm{Mg}^{2+}, \mathrm{Ca}^{2+}, \mathrm{SiO}_{2}{ }^{0}, \mathrm{OH}, \mathrm{or}_{2} \mathrm{O}$.

${ }^{b}$ experimental data from [44] 


\section{RESULTS AND DISCUSSION}

\section{1. $\quad \mathrm{C}-\mathrm{S}-\mathrm{H}+\mathrm{MgCl}_{2}$}

The addition of $\mathrm{MgCl}_{2}$ to pre-synthesized C-S-H lowers the $\mathrm{pH}$ values (as discussed below) and destabilizes the C-S-H. The TGA curves of $\mathrm{M}-\mathrm{S}-\mathrm{H}, \mathrm{C}-\mathrm{S}-\mathrm{H}$ and $\mathrm{C}-\mathrm{S}-\mathrm{H}$ plus $\mathrm{MgCl}_{2}$ and the derivative weight losses are shown in Figure 1 . The first water loss region between $30{ }^{\circ} \mathrm{C}$ and 250 ${ }^{\circ} \mathrm{C}$ is characteristic for both $\mathrm{C}-\mathrm{S}-\mathrm{H}[17,37,45]$ and $\mathrm{M}-\mathrm{S}-\mathrm{H}[11,15,37,46]$ and has been related to poorly bound water on the surface or in the interlayer. In the case of pure $\mathrm{C}-\mathrm{S}-\mathrm{H}$, the second water loss between $250{ }^{\circ} \mathrm{C}$ and $800{ }^{\circ} \mathrm{C}$ is related to the calcium or silanol hydroxyl group [37, 45]. In M-S-H this second water loss corresponds to magnesium and silanol hydroxyl group in M-S-H $[11,15,16,37,46]$, is more distinct and centered at $570{ }^{\circ} \mathrm{C}$ (Figure 1) as already reported by [35]. The TGA data indicate the presence of hydrates (C-S-H or M-S-H) in the samples, while no brucite (water loss in a narrow range at around $400{ }^{\circ} \mathrm{C}[11,15,16,46]$ ), nor portlandite (water loss in a narrow range at around $550^{\circ} \mathrm{C}$ [37]) are detected, indicating their absence. Traces of calcite $\left(<1\right.$ wt.\% ) are observed (weight loss at around $750-800{ }^{\circ} \mathrm{C}$ [37]). The presence of M-S-H is clearly detected in the sample with the maximum of $\mathrm{MgCl}_{2}$ addition, while at lower $\mathrm{MgCl}_{2}$ additions mainly C-S-H and only small quantities of M-S-H seem to be present. 


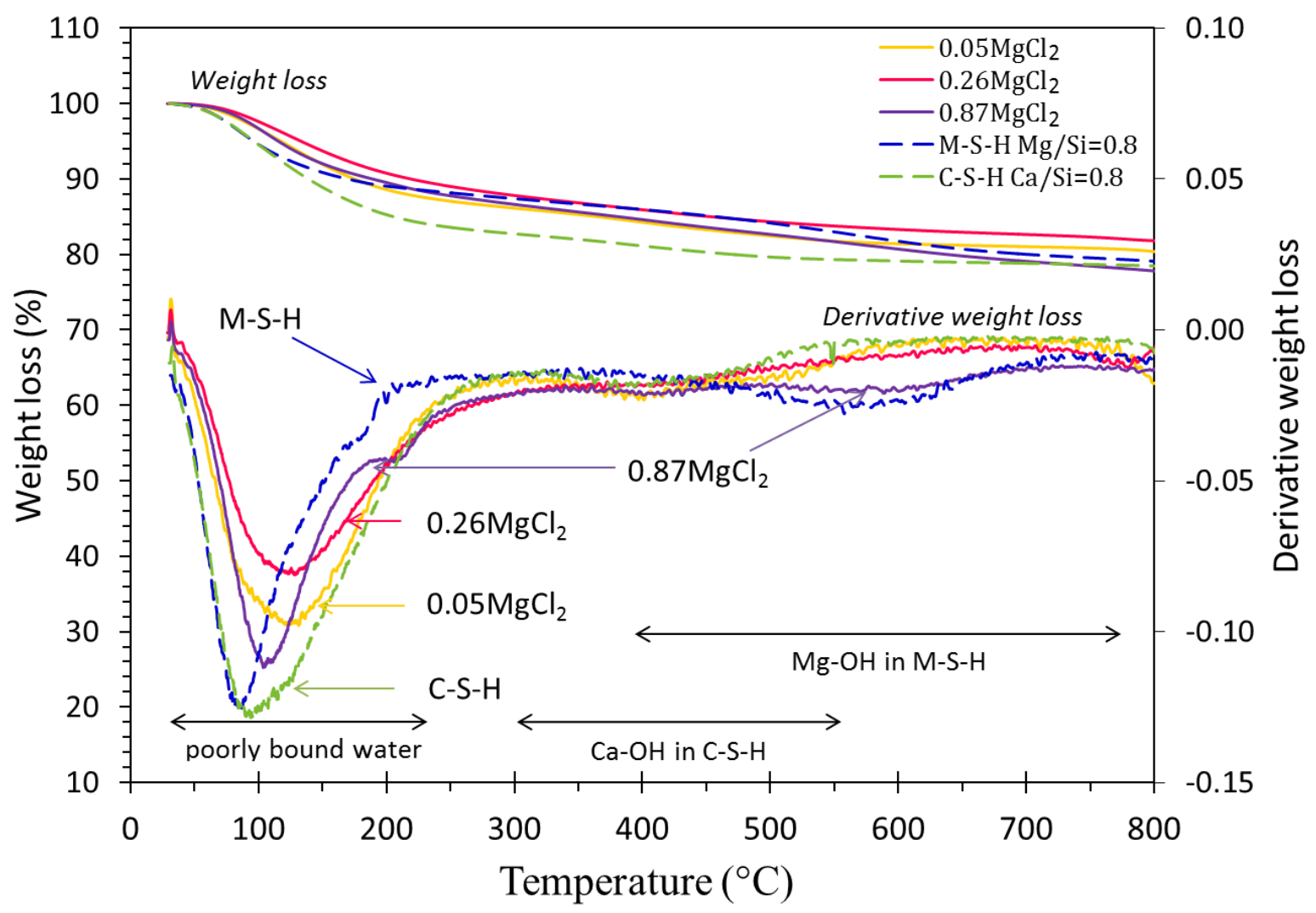

Figure 1: Thermogravimetric analysis (TGA) of C-S-H samples where $\mathrm{MgCl}_{2}$ has been added: $0.05 \mathrm{MgCl}, 0.26$ $\mathrm{MgCl}_{2}$ and $0.87 \mathrm{MgCl}_{2}$ (solid lines) after 1 year of curing at $20^{\circ} \mathrm{C}, \mathrm{TGA}$ of $\mathrm{M}-\mathrm{S}-\mathrm{H} 0.8$ and $\mathrm{C}-\mathrm{S}-\mathrm{H} 0.8$ (dashed lines) are shown as references.

The XRD measurements are shown in Figure 2. The patterns of pure C-S-H and M-S-H show broad reflections related to the nanosize of the particles [16, 47-49]. The characteristic reflections of C-S-H are located at $16.3,29.2,32.0$ and $43.0^{\circ}$ 2theta [35] as detailed in Figure 2. With the addition of $\mathrm{MgCl}_{2}$, the reflections of C-S-H decrease while $\mathrm{M}-\mathrm{S}-\mathrm{H}$ is observed by the additional broad reflections at 19.7 and $35.0^{\circ}$ 2theta [15] in the samples $0.26 \mathrm{MgCl}_{2}$ and $0.87 \mathrm{MgCl}_{2}$. Peak shifts relative to pure phases, i.e. $\mathrm{M}-\mathrm{S}-\mathrm{H}$ or $\mathrm{C}-\mathrm{S}-\mathrm{H}$, are not observed confirming the presence of C-S-H and/or M-S-H as separate phases, as previously observed by a few authors [34, 35]. 


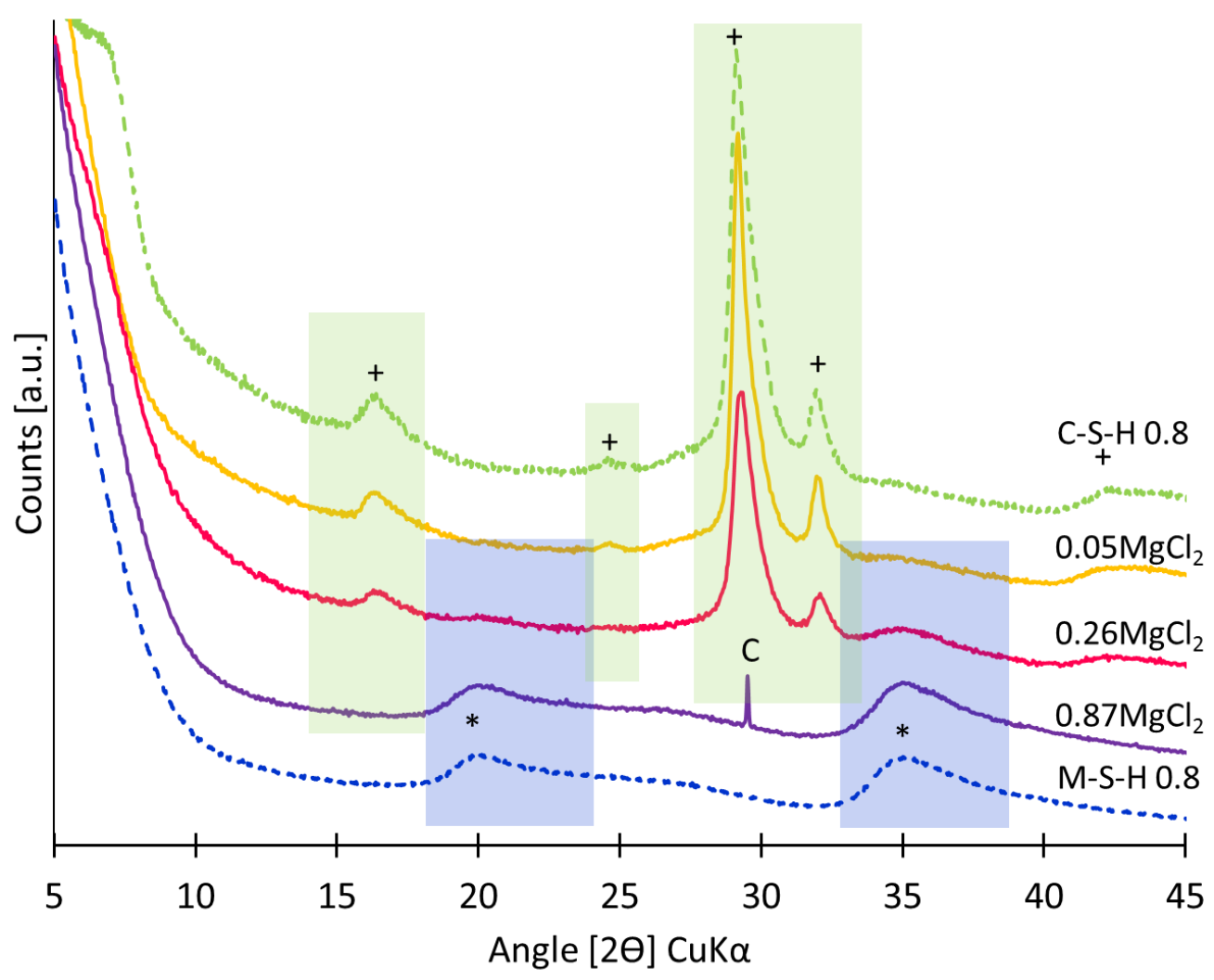

Figure 2: XRD patterns of $\mathrm{C}-\mathrm{S}$-H samples where $\mathrm{MgCl}_{2}$ has been added: $0.05 \mathrm{MgCl}, 0.26 \mathrm{MgCl}_{2}$ and $0.87 \mathrm{MgCl}_{2}$ (solid lines) after 1 year of curing at $20{ }^{\circ} \mathrm{C}$, patterns of $M-S-H 0.8$ and $C-S-H 0.8$ (dashed lines) shown as references, $C=$ calcite. The area of the main reflections of $C-S-H$ and $M-S-H$ are shaded $\left(+=C-S-H,{ }^{*}=M-S-H\right)$.

The FTIR spectra of these samples are shown in Figure 3. The characteristic bands of C-S-H with a Ca/Si equal to 0.8 are centered at $\sim 950-980 \mathrm{~cm}^{-1}$ and at $800-825 \mathrm{~cm}^{-1}$ and are assigned to $\mathrm{Si}-\mathrm{O}$ stretching vibrations of the $\mathrm{Q}^{2}$ and $\mathrm{Q}^{1}$ respectively [50], while the bands centrered at $\sim 990$ $1000 \mathrm{~cm}^{-1}$ and $\sim 870-880 \mathrm{~cm}^{-1}$ correspond to the $\mathrm{Q}^{3}$ and $\mathrm{Q}^{2}$ of the M-S-H $[11,15]$ as detailed in Figure 3. The Raman bands characteristic of C-S-H [51-54] are given in Figure 4. Raman bands of M-S-H [15, 35] attributed by [15] by comparison with spectra of talc [54] and antigorite [55] are detailed in Figure 4 as well. The $\mathrm{Si}-\mathrm{O}-\mathrm{Si}$ bending of $\mathrm{M}-\mathrm{S}-\mathrm{H}$ is at a higher wavenumber $\left(675 \mathrm{~cm}^{-1}\right)$ than the one of $\mathrm{C}-\mathrm{S}-\mathrm{H}\left(660 \mathrm{~cm}^{-1}\right)$. A broadening of the $\mathrm{C}-\mathrm{S}-\mathrm{H}$ bands due to the apperance of M-S-H $\left(675 \mathrm{~cm}^{-1}\right)$ is already observed at the smallest $\mathrm{MgCl}_{2}$ addition. At higher 
$\mathrm{MgCl}_{2}$ additions, a clear band at $1000 \mathrm{~cm}^{-1}$ is visible. Similar to the XRD data, FTIR and Raman measurements indicate the absence of any significant amount of $\mathrm{C}-\mathrm{S}-\mathrm{H}$ in the $0.87 \mathrm{MgCl}_{2}$ sample.

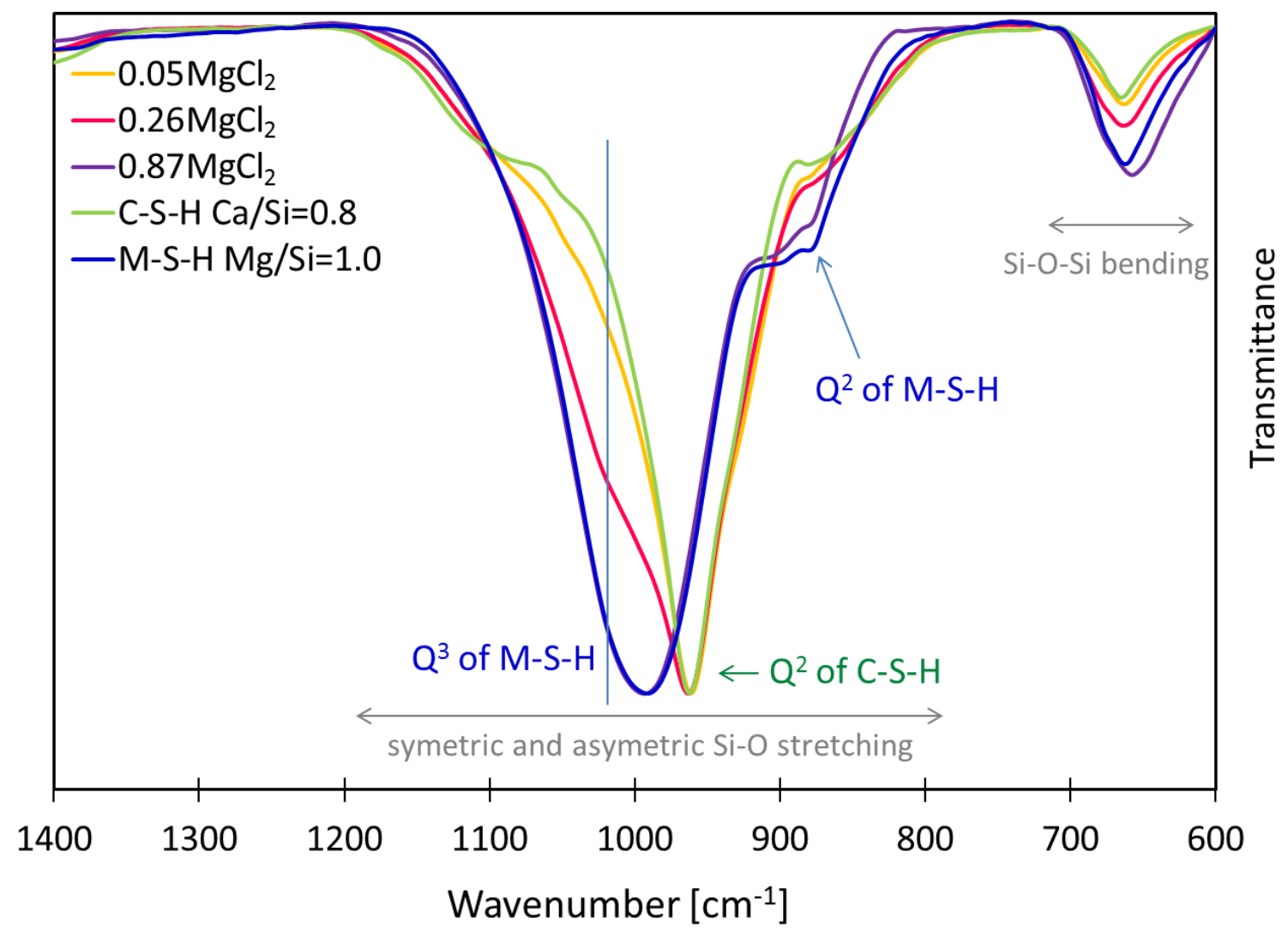

Figure 3: FTIR spectra of C-S-H samples where $\mathrm{MgCl}_{2}$ has been added: $0.05 \mathrm{MgCl}_{2}, 0.26 \mathrm{MgCl}_{2}$ and $0.87 \mathrm{MgCl}_{2}$ after 1 year of curing at $20{ }^{\circ} \mathrm{C}$, spectra of $M-S-H 0.8$ and $C$-S-H 0.8 shown as references (the vertical line indicates the shoulder due to the $Q^{3}$ silicate sites in $\left.M-S-H\right)$. 


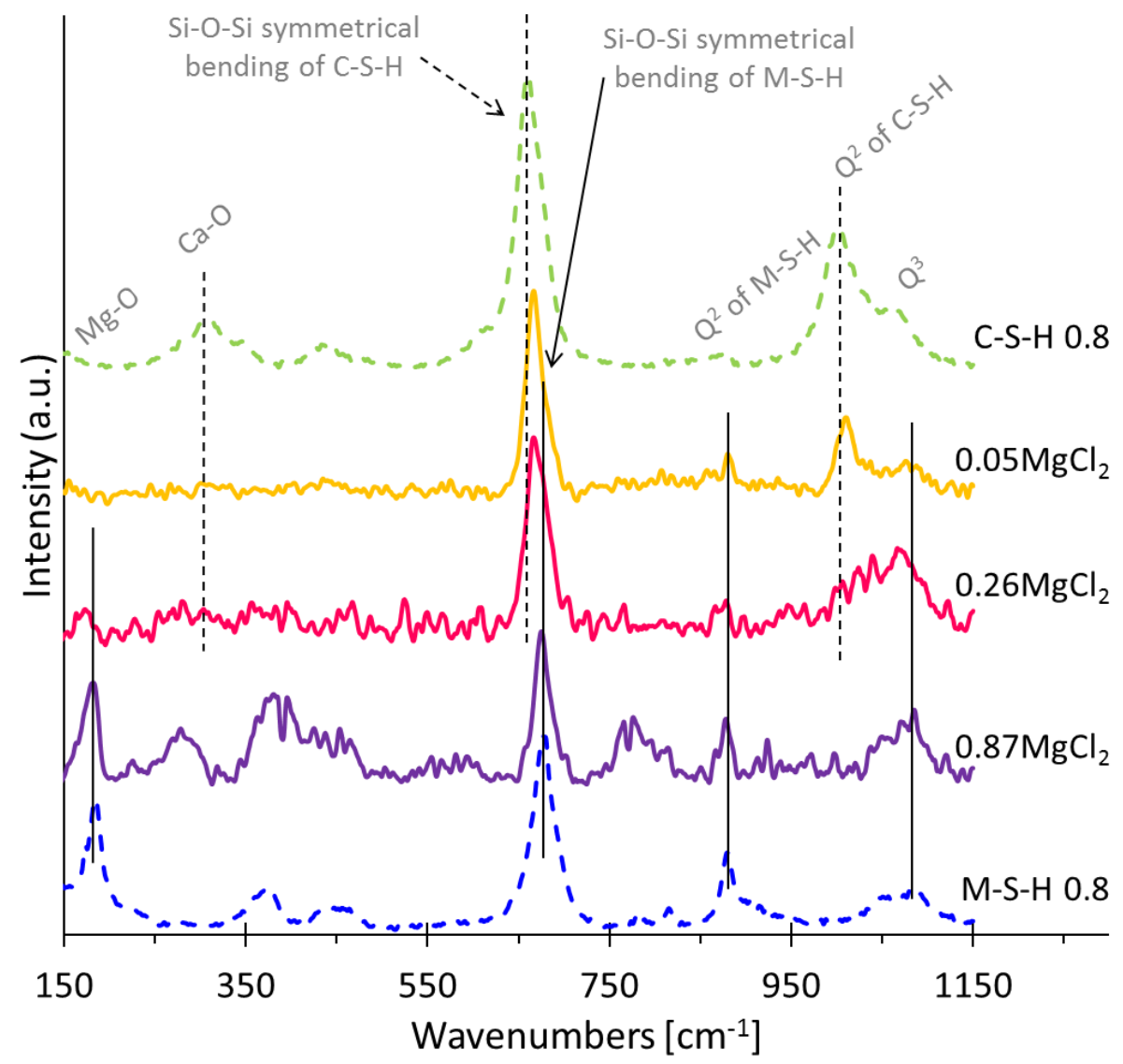

Figure 4: Raman spectra of C-S-H samples where $\mathrm{MgCl}_{2}$ has been added: $0.05 \mathrm{MgCl}_{2}, 0.26 \mathrm{MgCl}_{2}$ and $0.87 \mathrm{MgCl}_{2}$, $\mathrm{C}-\mathrm{S}-\mathrm{H}$ and $\mathrm{M}-\mathrm{S}-\mathrm{H}$, after 1 year of curing at $20^{\circ} \mathrm{C}$, assignments of the band according to [31-34] for C-S-H and [10, 21] for $M-S-H$.

The ${ }^{29} \mathrm{Si}$ MAS NMR spectra of these samples are shown in Figure 5. The structure of C-S-H is well investigated [26, 36, 56-59]; the characteristic shifts at $\simeq-79.7,-82.9,-85.5$ and $-88.4 \mathrm{ppm}$, which correspond to $\mathrm{Q}^{1}$ (end of chains), $\mathrm{Q}_{\mathrm{b}}^{2}$ (bridging position), $\mathrm{Q}_{\mathrm{p}}^{2}$ (pairing position) and $\mathrm{Q}_{\mathrm{u}}^{2}$ (bridging position with binding to $\mathrm{H}^{+}[36,60,61]$ ) of the silicate tetrahedra in C-S-H are visible in Figure 5. ${ }^{29} \mathrm{Si}$ MAS NMR studies have shown that at high $\mathrm{Ca} / \mathrm{Si}$, no cross linked silicate groups $\left(\mathrm{Q}^{3}\right)$ exist in pure C-S-H, while very small quantities of $\mathrm{Q}^{3}$ with a chemical shift between -95 and $-97 \mathrm{ppm}[40,60]$ have been reported for $\mathrm{C}-\mathrm{S}-\mathrm{H}$ with low $\mathrm{Ca} / \mathrm{Si}$. Our C-S-H reference sample contains approximately $4 \%$ (quantification detailed below) of the total silica in a broad 
signal at $-93.5 \mathrm{ppm}$. The presence of $\mathrm{Q}^{3}$ signals in higher quantities between -92 and $-97 \mathrm{ppm}$ indicates the formation of $\mathrm{M}-\mathrm{S}-\mathrm{H}[11,13,15,16,27,28]$ even at very low $\mathrm{MgCl}_{2}$ addition $\left(0.05 \mathrm{MgCl}_{2}\right)$ (Figure 5). At higher $\mathrm{MgCl}_{2}$ addition the intensity of the chemical shifts of the C-S-H decreases while the amount of $\mathrm{Q}^{3}$ tetrahedra sites, indicating the presence of $\mathrm{M}-\mathrm{S}-\mathrm{H}$, increases. Although the peaks decrease, the relative intensity and the position of the chemical shifts of C-S-H, when present, do not change significantly, indicating that the polymerization of the silicates in the $\mathrm{C}-\mathrm{S}-\mathrm{H}$ remains constant. The $0.87 \mathrm{MgCl}_{2}$ sample spectrum, similar to $\mathrm{M}-\mathrm{S}-\mathrm{H}$ spectra $(\mathrm{Mg} / \mathrm{Si}=0.80$ and 1.0$)$, indicates no or very little $\mathrm{C}-\mathrm{S}-\mathrm{H}$. However the shift of the $\mathrm{Q}^{2}$ signal to less negative values could indicate the persistence of some $\mathrm{C}-\mathrm{S}-\mathrm{H}$ in the $0.87 \mathrm{MgCl}_{2}$ sample.

The deconvolutions of the ${ }^{29} \mathrm{Si}$ MAS NMR spectra were done following the procedure outlined in $[11,15,17]$ and are presented in Table 3 . The deconvolutions of the samples with additional $\mathrm{MgCl}_{2}$ are associated with considerable $( \pm 10 \%)$ error due to the overlapping of the chemical shifts of ${ }^{29} \mathrm{Si}$ for $\mathrm{M}-\mathrm{S}-\mathrm{H}$ and $\mathrm{C}-\mathrm{S}-\mathrm{H}$. The $\mathrm{Q}^{3}$ tetrahedra sites have been attributed to $\mathrm{M}-\mathrm{S}-\mathrm{H}$ with the exception of the 3-4\% at $-93.5 \mathrm{ppm}$ which was already present in pure $\mathrm{C}-\mathrm{S}-\mathrm{H}$. The attribution of the $\mathrm{Q}^{2}$ tetrahedra signal of $\mathrm{M}-\mathrm{S}-\mathrm{H}$ has been made with keeping the ratio $\mathrm{Q}^{2} / \mathrm{Q}^{3}$ in $\mathrm{M}-\mathrm{S}-\mathrm{H}$ low (0.4-0.6), respecting Equation (2) and allowing a high MCL (>20) in the structure of C-S-H.

Deconvolutions of the ${ }^{29} \mathrm{Si}$ MAS NMR data indicate that approximately $7 \% \pm 3 \%$ is attributed to silica in $\mathrm{M}-\mathrm{S}-\mathrm{H}$ in the sample $0.05 \mathrm{MgCl}_{2}, 44 \% \pm 7 \%$ in the sample $0.26 \mathrm{MgCl}_{2}$ while $87 \%$ $\pm 11 \%$ and $53 \% \pm 8 \%$ are attributed to $\mathrm{C}-\mathrm{S}-\mathrm{H}$ in the samples $0.05 \mathrm{MgCl}_{2}$ and $0.26 \mathrm{MgCl}_{2}$. The silica content in C-S-H decreases as M-S-H is formed. All the silica (98\%) has been attributed to $\mathrm{M}-\mathrm{S}-\mathrm{H}$ in the sample $0.87 \mathrm{MgCl}_{2}$ although the $\mathrm{Q}^{2}$ signal is broader than in pure $\mathrm{M}-\mathrm{S}-\mathrm{H}$. The $\mathrm{Ca} / \mathrm{Si}$ in C-S-H, when present, have been estimated from the MCL [20] and is detailed in Table 3. 


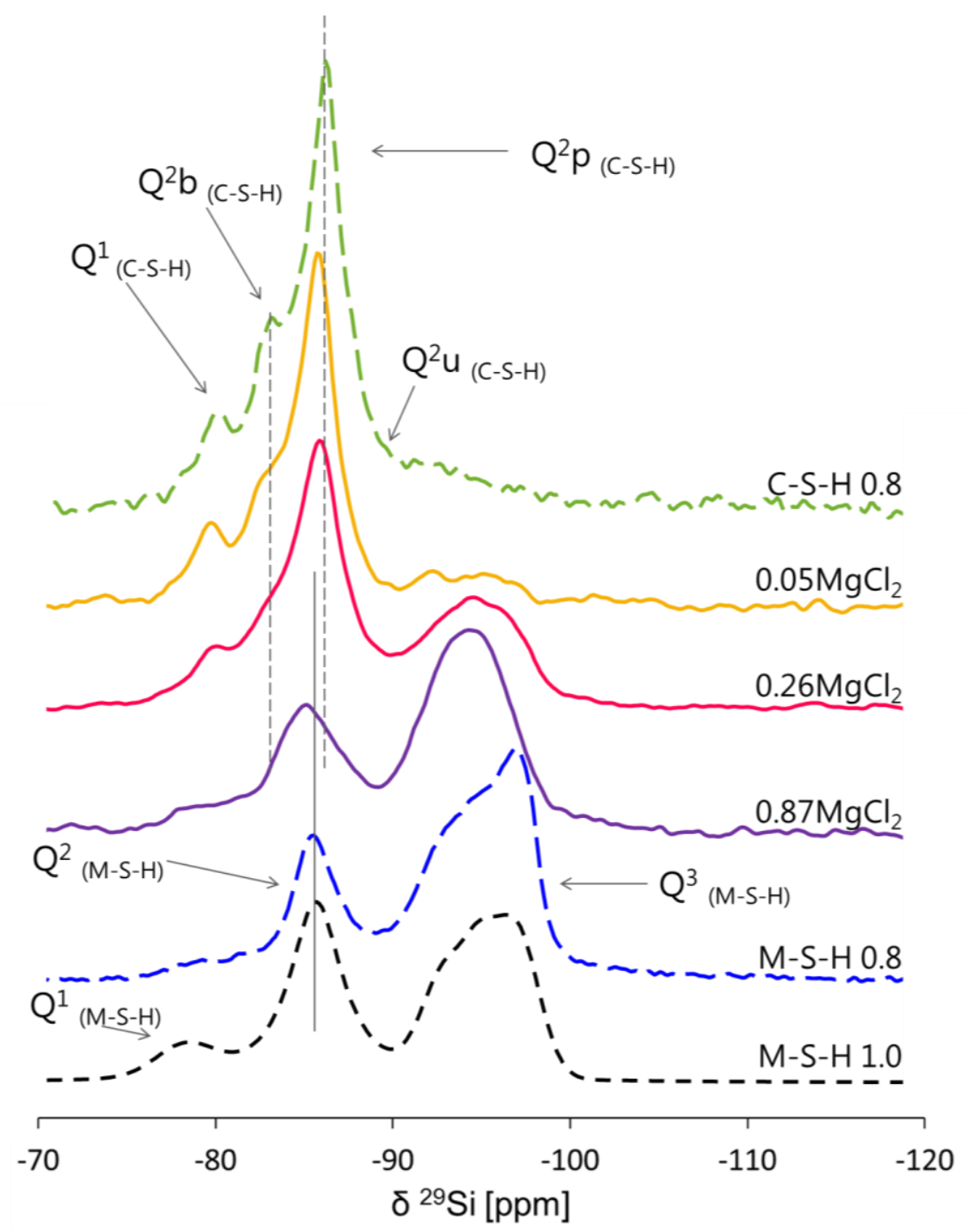

Figure 5: ${ }^{29} \mathrm{Si}$ MAS NMR spectra of C-S-H samples where $\mathrm{MgCl}_{2}$ has been added: $0.05 \mathrm{MgCl}_{2}, 0.26 \mathrm{MgCl}_{2}$ and 0.87 $\mathrm{MgCl}_{2}$ after 1 year of curing at $20^{\circ} \mathrm{C}$, (C-S-H and M-S-H shown as references).

Table 3:Peak shifts and relative intensities (quantifications) of different silicon shifts obtained from the deconvolution of the ${ }^{29} \mathrm{Si}$ MAS NMR spectra for C-S-H samples where $\mathrm{MgCl}_{2}$ has been added: $0.05 \mathrm{MgCl}_{2}, 0.26 \mathrm{MgCl}_{2}$ and $0.87 \mathrm{MgCl}_{2}$ after 1 year of curing at $20^{\circ} \mathrm{C}$ (C-S-H and M-S-H shown as references) ( $\delta^{29} \mathrm{Si}$ in ppm $\pm 0.3 \mathrm{ppm}$ ).

\begin{tabular}{|c|c|c|c|c|c|c|c|c|c|c|c|c|c|c|c|c|}
\hline & \multicolumn{3}{|c|}{$\delta^{29} \mathrm{Si}(\mathrm{C}-\mathrm{S}-\mathrm{H})$} & $Q^{2} u$ & \multirow{2}{*}{$\mathrm{MCL}$} & \multirow{2}{*}{$\mathrm{Ca} / \mathrm{Si}$} & \multirow{2}{*}{$\begin{array}{c}Q^{3} \\
-93.5\end{array}$} & \multicolumn{5}{|c|}{$\delta^{29} \mathrm{Si}(\mathrm{M}-\mathrm{S}-\mathrm{H})$} & & \multicolumn{3}{|c|}{ Total in } \\
\hline & -79.6 & -82.8 & -85.8 & -88.2 & & & & -78.3 & -85.5 & -92.7 & -94.7 & -96.7 & $\mathrm{Q}^{2} / \mathrm{Q}^{3}$ & -100.9 & & ilica \\
\hline C-S-H 0.8 & 8 & 22 & 59 & 7 & 25 & & 4 & - & - & - & - & - & - & - & 96 & - \\
\hline $0.05 \mathrm{MgCl}_{2}$ & 8 & 25 & 53 & 2 & 22 & 0.77 & 4 & 1 & 2 & 1 & 2 & 1 & 0.6 & 1 & 87 & 7 \\
\hline M-S-H 0.8 & - & - & - & - & - & & - & 2 & 34 & 23 & 8 & 27 & 0.6 & 6 & - & 94 \\
\hline M-S-H 1.0 & - & - & - & - & - & & - & 5 & 43 & 17 & 9 & 26 & 0.8 & - & - & 100 \\
\hline
\end{tabular}

Quantification error $\simeq \pm 10 \%$ of absolute amounts of (\%Si) $+2.5 \%$ 
The $\mathrm{pH}$ values and measured concentrations of the solution for samples cured for 3 months and 1 year at $20^{\circ} \mathrm{C}$ are plotted in Figure 6 and detailed with the additional results at $50^{\circ} \mathrm{C}$ in Table 4 . The addition of $\mathrm{MgCl}_{2}$ to $\mathrm{C}-\mathrm{S}-\mathrm{H}$ decreases the $\mathrm{pH}$ value from 10.5 in the solution equilibrated with $\mathrm{C}-\mathrm{S}-\mathrm{H}$ only $(\mathrm{Ca} / \mathrm{Si}=0.8)$ to $\mathrm{pH} 7.7$ at the maximum $\mathrm{MgCl}_{2}$ addition $\left(1.34 \mathrm{MgCl}_{2}\right.$ sample). The calcium concentrations increase with the addition of $\mathrm{MgCl}_{2}$ up to $130 \mathrm{mM}[\mathrm{Ca}]$ at $20^{\circ} \mathrm{C}$ and up to $140 \mathrm{mM}[\mathrm{Ca}]$ at $50^{\circ} \mathrm{C}$ and reach a plateau at $\mathrm{Mg} / \mathrm{Si} \geq 0.87$. Thus 93 to $100 \%$ of the initially present calcium (Table 1) is in the solution indicating the dissolution of C-S-H and possibly the uptake of some calcium in the M-S-H. This is in agreement with the ${ }^{29} \mathrm{Si}$ MAS NMR results in Figure 5, where only M-S-H was clearly observed. The destabilization of C-S-H at pH values below 9.5 is in agreement with studies on the stability of C-S-H upon leaching [62-65]. The silicon concentrations, however, remain below the concentrations in equilibrium with respect to amorphous silica (1-2 mM), which indicates the formation of another silica containing solid, i.e. M-S-H. 


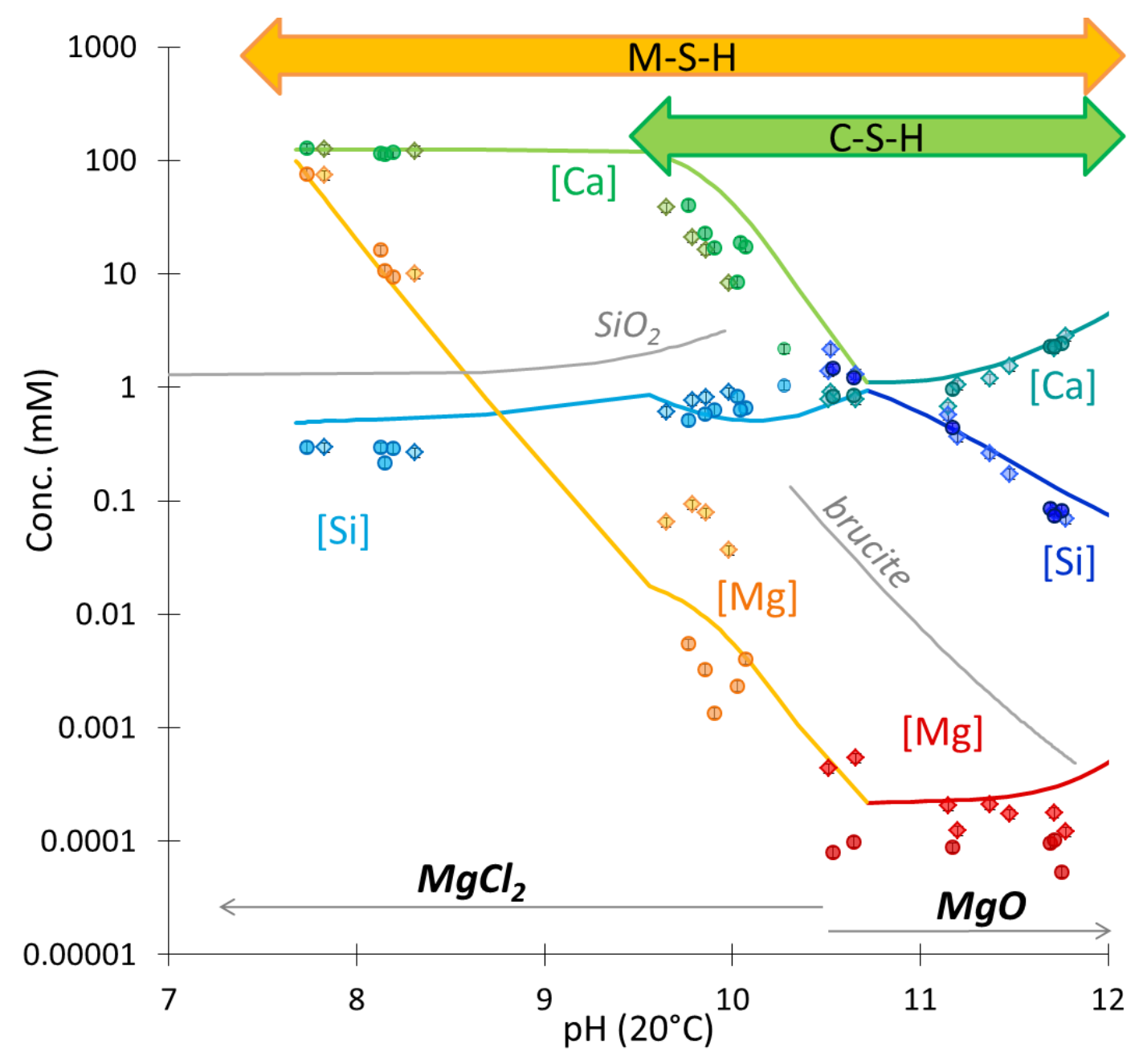

Figure 6: Measured silicon, magnesium, and calcium as a function of pH (diamond: 3 months, circles: 12 months) and calculated solubility curves of $C-S-H$ and M-S-H using the solid-solution's models. Solubility's of brucite and amorphous $\mathrm{SiO}_{2}$ are indicated in grey.

The magnesium concentrations are very low in the case of low $\mathrm{MgCl}_{2}$ additions (samples $0.05 \mathrm{MgCl}_{2}$ up to $0.26 \mathrm{MgCl}_{2}$ ) at the $\mathrm{pH}$ values $\geq 9.7$, indicating that the magnesium initially added reacts directly with the amorphous silica from the dissolution of $\mathrm{C}-\mathrm{S}-\mathrm{H}$, consistent with the observation of M-S-H by ${ }^{29} \mathrm{Si}$ MAS NMR. Only for relatively high $\mathrm{MgCl}_{2}$ additions $\left(0.87 \mathrm{MgCl}_{2}\right.$, $1.33 \mathrm{MgCl}_{2}$ ) at $\mathrm{pH}$ values lower than 8.3 , higher magnesium concentrations are observed. The magnesium concentrations increase with the $\mathrm{MgCl}_{2}$ addition up to $\approx 80 \mathrm{mM}$ at $\mathrm{pH} 7.7$, i.e. up to 
one third of the total magnesium present (see Table 1). The strong increase of magnesium could indicate that $\mathrm{M}-\mathrm{S}-\mathrm{H}$ is expected to be not stable below a $\mathrm{pH}$ of $\sim 7.5$. The measured concentrations show little variations between 3 and 12 months indicating that the formation of $\mathrm{M}-\mathrm{S}-\mathrm{H}$ is relatively fast under these lower $\mathrm{pH}$ conditions, while the formation of $\mathrm{M}-\mathrm{S}-\mathrm{H}$ from $\mathrm{MgO}$ and $\mathrm{SiO}_{2}$ needs several months to years to reach equilibrium $[9-12,15]$.

Table 4: Summary of the presence of brucite and unreacted silica in the solid composition, the measured dissolved concentrations, $p H$ values in the solutions in equilibrium with the C-S-H and the magnesium additions samples at $20^{\circ} \mathrm{C}$ and $50^{\circ} \mathrm{C}$ after 3 months and 1 year. M-S-H samples from [11] have been added as references (bold samples indicate that the solid has been analyzed in detail).

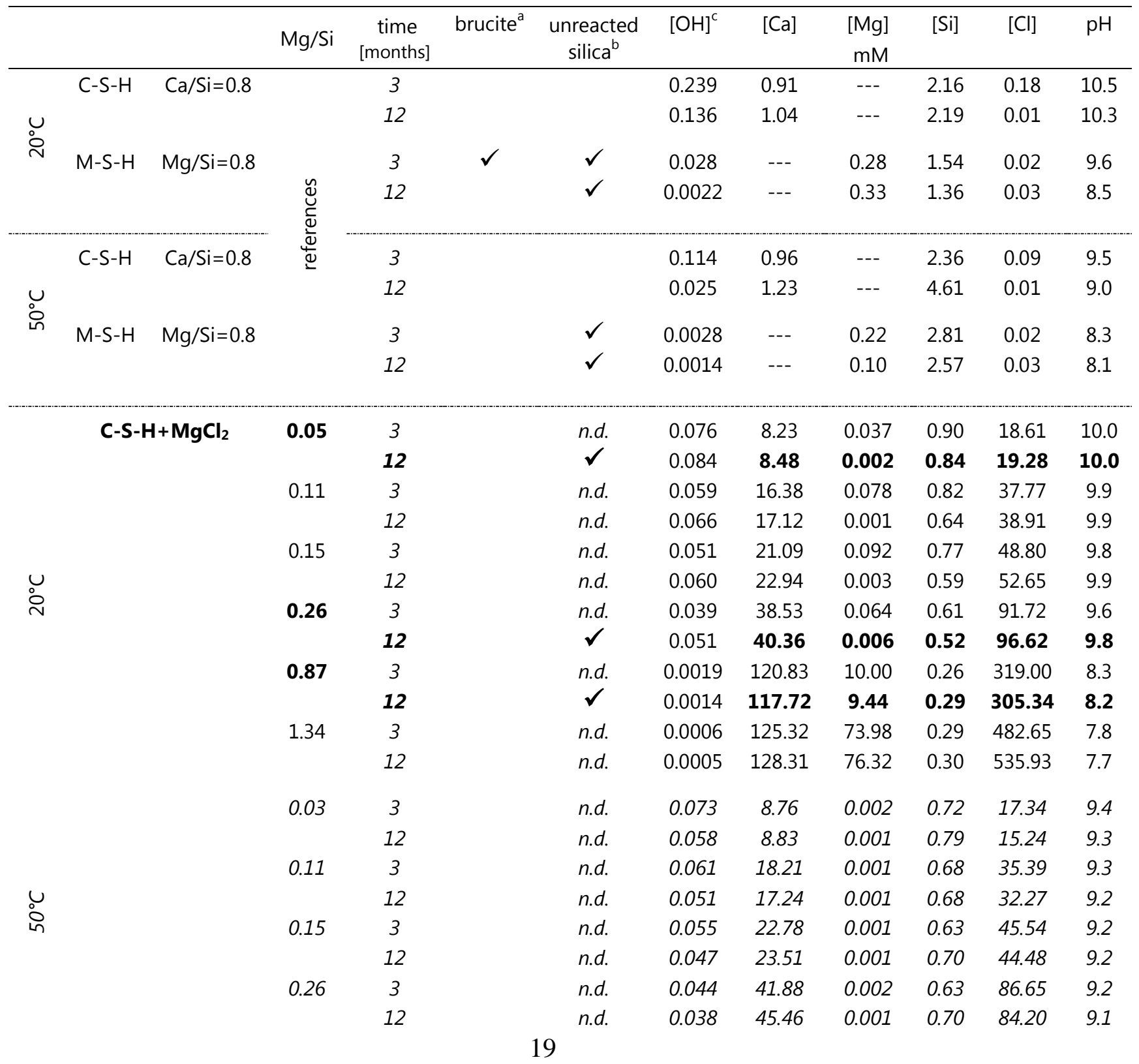




\begin{tabular}{|c|c|c|c|c|c|c|c|c|c|c|c|}
\hline & 0.87 & \multicolumn{2}{|l|}{3} & n.d. & 0.0009 & 125.40 & 7.03 & 0.61 & 288.18 & 7.8 \\
\hline & & & \multicolumn{2}{|l|}{12} & n.d. & 0.0007 & 135.72 & 10.67 & 0.68 & 328.61 & 7.7 \\
\hline & & 1.34 & \multicolumn{2}{|l|}{3} & n.d. & 0.0003 & 134.32 & 77.00 & 0.66 & 433.25 & 7.4 \\
\hline & & & \multicolumn{2}{|l|}{12} & n.d. & 0.0003 & 145.38 & 84.57 & 0.64 & 466.22 & 7.4 \\
\hline \multirow{8}{*}{ ¿̊ } & \multirow[t]{16}{*}{ C-S-H+MgO } & 0.04 & 3 & $\checkmark$ & n.d. & 0.324 & 0.79 & 0.0005 & 1.31 & 0.17 & 10.7 \\
\hline & & & 12 & $\checkmark$ & & 0.243 & 0.84 & 0.0001 & 1.47 & 0.01 & 10.5 \\
\hline & & 0.23 & 3 & $\checkmark$ & n.d. & 2.176 & 1.54 & 0.0002 & 0.17 & 0.1 & 11.5 \\
\hline & & & 12 & $\checkmark$ & $\checkmark$ & 1.066 & 0.97 & 0.0001 & 0.44 & 0.01 & 11.2 \\
\hline & & 0.59 & 3 & $\checkmark$ & n.d. & 4.427 & 2.85 & 0.0001 & 0.07 & 0.09 & 11.8 \\
\hline & & & 12 & $\checkmark$ & & 3.614 & 2.30 & 0.0001 & 0.09 & 0.01 & 11.7 \\
\hline & & 0.86 & 3 & $\checkmark$ & n.d. & 3.780 & 2.21 & 0.0002 & 0.08 & 0.01 & 11.7 \\
\hline & & & 12 & $\checkmark$ & n.d. & 3.790 & 2.31 & 0.0001 & 0.07 & 0.01 & 11.7 \\
\hline \multirow{8}{*}{ 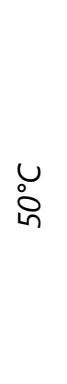 } & & 0.04 & 3 & $\checkmark$ & n.d. & 0.298 & 0.79 & 0.0002 & 1.15 & 0.16 & 9.9 \\
\hline & & & 12 & $\checkmark$ & n.d. & 0.276 & 0.84 & 0.0001 & 1.05 & 0.01 & 9.8 \\
\hline & & 0.23 & 3 & $\checkmark$ & n.d. & 2.587 & 1.84 & 0.0002 & 0.11 & 0.46 & 10.6 \\
\hline & & & 12 & $\checkmark$ & n.d. & 1.619 & 1.43 & 0.0001 & 0.14 & 0.01 & 10.4 \\
\hline & & 0.59 & 3 & $\checkmark$ & n.d. & 4.763 & 3.17 & 0.0002 & 0.07 & 0.14 & 10.8 \\
\hline & & & 12 & $\checkmark$ & n.d. & 4.127 & 2.96 & 0.0001 & 0.06 & 0.01 & 10.8 \\
\hline & & 0.86 & 3 & $\checkmark$ & n.d. & 5.844 & 3.68 & 0.0001 & 0.06 & 0.49 & 10.9 \\
\hline & & & 12 & $\checkmark$ & n.d. & 5.217 & 3.48 & 0.0001 & 0.05 & 0.01 & 10.8 \\
\hline
\end{tabular}

afrom TGA,

${ }^{b}$ from ${ }^{29}$ Si MAS NMR,

${ }^{c}$ Hydroxide concentrations calculated from the measured $p H$ values

Magnesium's detection limit: $0.00001 \mathrm{mM}$

To investigate whether any calcium remained in the M-S-H, three of the samples have been dissolved in $0.1 \mathrm{M} \mathrm{HCl}$. The results in Table 5 show a $\mathrm{Ca} / \mathrm{Mg}$ ratio in the $\mathrm{M}-\mathrm{S}-\mathrm{H}$ of only $0.006 \pm$ 0.01 for the sample with $\mathrm{Mg} / \mathrm{Si}=0.87$, thus confirming the complete destabilization of $\mathrm{C}-\mathrm{S}-\mathrm{H}$ and pointing towards no or a very low uptake of calcium within the M-S-H structure.

The magnesium measurements summarized in Table 5 agree well with the total amounts present as given in Table 1, which indicates a good accuracy of the measured aqueous concentrations. The measured calcium content in the solid together with the liquid phase is with $13.1 \pm 1.5$ to $14.5 \pm 1.6 \mathrm{mmol}$ somewhat lower than the $15.2 \mathrm{mmol}$ of calcium initially used, which indicates either an underestimation of the measured calcium concentrations, the presence of less calcium in the C-S-H than expected or the removal of calcium ions loosely associated in the diffusive layer 
of M-S-H and C-S-H during washing with isopropanol and water. The slight decrease of the amount of measured total calcium in the samples with very high dissolved calcium (sample $0.87 \mathrm{MgCl}_{2}$ ), could point towards a removal of calcium during the washing process and thus to the presence of some calcium at the surface of M-S-H even if effect of errors during the preparation of the samples, filtration and IC measurements cannot be excluded.

The $\mathrm{Mg} / \mathrm{Si}$ and $\mathrm{Ca} / \mathrm{Si}$ in $\mathrm{M}-\mathrm{S}-\mathrm{H}$ and $\mathrm{C}-\mathrm{S}-\mathrm{H}$ have been calculated from the measured $\mathrm{Ca}$ and $\mathrm{Mg}$ in the solid part taking into account only the amount of silicate associated with M-S-H or C-S-H from the ${ }^{29} \mathrm{Si}$ MAS NMR analysis. For the $0.26 \mathrm{MgCl}_{2}$ sample $\mathrm{Ca} / \mathrm{Si}(0.5 \pm 0.3)$ and $\mathrm{Mg} / \mathrm{Si}(0.6 \pm$ 0.2 ) ratios have been determined. These ratios are in agreement with the 0.67 usually reported for C-S-H and the 0.67-0.8 [10-13, 15] for M-S-H.

Table 5: Composition of the solids from dissolution, of the aqueous phase from filtration, the total experimentally determined and the experimentally determined ratios $\mathrm{Mg} / \mathrm{Si}$ in $\mathrm{M}-\mathrm{S}-\mathrm{H}$ and $\mathrm{Ca} / \mathrm{Si}$ in $\mathrm{C}-\mathrm{S}$ - $\mathrm{H}$ from mass balance and ${ }^{29}$ Si MAS NMR deconvolutions.

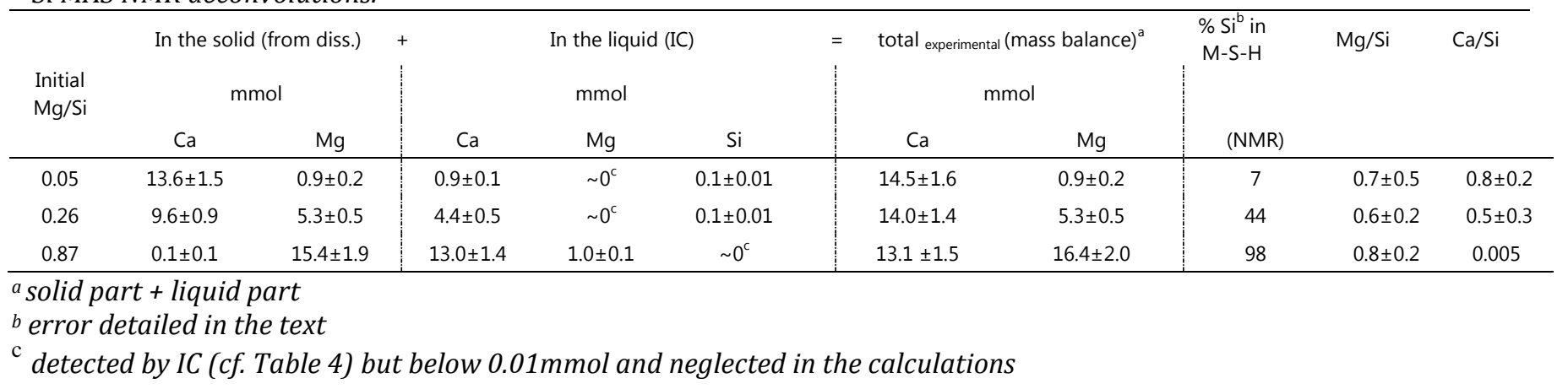

In summary, the different techniques indicate the destabilization of $\mathrm{C}-\mathrm{S}-\mathrm{H}$ and the formation of M-S-H upon the addition of $\mathrm{MgCl}_{2}$ even if only little $\mathrm{MgCl}_{2}\left(0.05 \mathrm{MgCl}_{2}\right)$ is added. C-S-H was observed to be unstable at $\mathrm{pH}$ values lower than 9.5 and $\mathrm{M}-\mathrm{S}-\mathrm{H}$ is expected to be destabilized at $\mathrm{pH}$ lower than 7.5. 


\section{1. $\quad \mathrm{C}-\mathrm{S}-\mathrm{H}+\mathrm{MgO}$}

The addition of $\mathrm{MgO}$ to $\mathrm{C}-\mathrm{S}-\mathrm{H}$ increases the $\mathrm{pH}$ values, in contrast to the $\mathrm{MgCl}_{2}$ additions. The XRD patterns and the TGA curves of the C-S-H samples with the different additions, $0.04 \mathrm{MgO}$, $0.23 \mathrm{MgO}$ and $0.59 \mathrm{MgO}$ (cf. Table 1), are shown in Figure 7 and Figure 8 respectively. Independently of the $\mathrm{MgO}$ additions, $\mathrm{C}-\mathrm{S}-\mathrm{H}$ is clearly observed by XRD and TGA in all the samples while no clear XRD reflections of M-S-H can be observed in contrast to the samples where $\mathrm{MgCl}_{2}$ had been added, as discussed previously. TGA data could indicate the formation of small quantities of M-S-H as visible by the minor water loss between $400-700^{\circ} \mathrm{C}$.

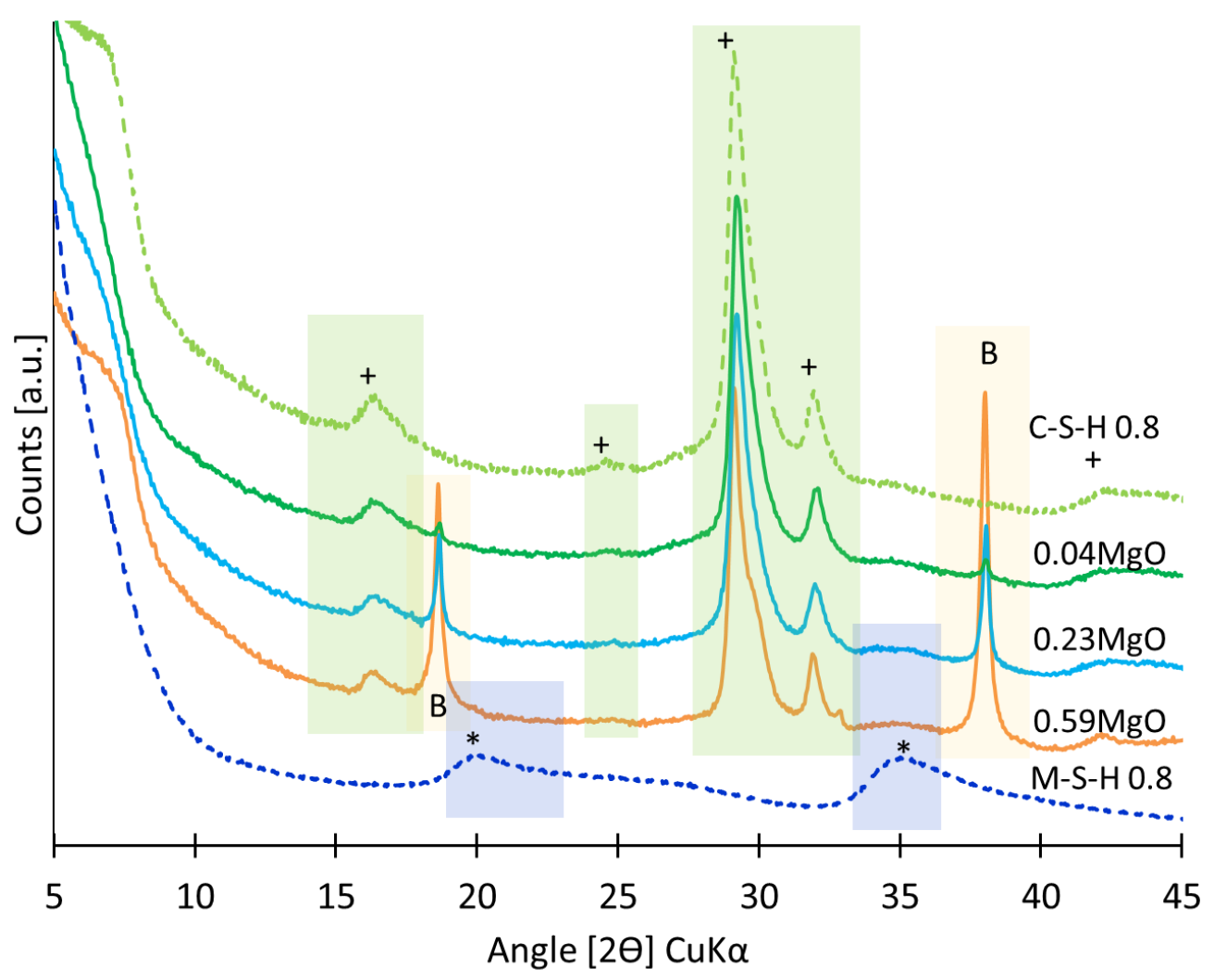

Figure 7: XRD patterns of C-S-H samples where $\mathrm{MgO}$ has been added: $0.04 \mathrm{MgO}, 0.23 \mathrm{MgO}$ and $0.59 \mathrm{MgO}$ after 1 year of curing at $20^{\circ} \mathrm{C}$, patterns of $M-S-H \quad 0.8$ and $C-S-H 0.8$ shown as references $\left(B=b r u c i t e ~\left(M g(O H)_{2}\right),+=C-S-H\right.$, $*=M-S-H)$. 


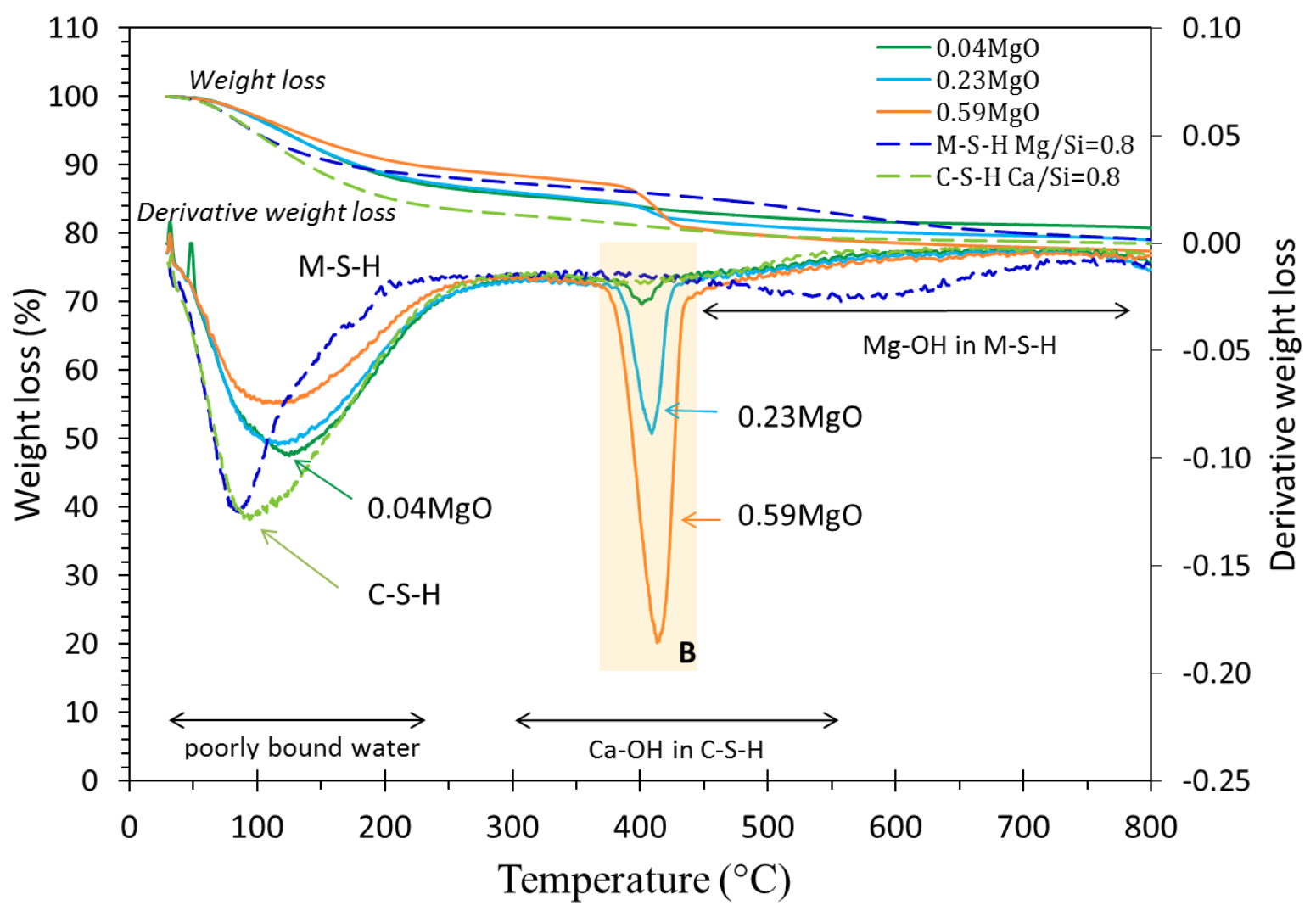

Figure 8: Thermogravimetric analysis of $\mathrm{C}-\mathrm{S}$ - $\mathrm{H}$ samples where $\mathrm{MgO}$ has been added: $0.04 \mathrm{MgO}, 0.23 \mathrm{MgO}$ and $0.59 \mathrm{MgO}$ after 1 year of curing at $20^{\circ} \mathrm{C}$, patterns of $\mathrm{M}-\mathrm{S}-\mathrm{H} 0.8$ and $\mathrm{C}-\mathrm{S}-\mathrm{H} 0.8$ shown as references. B=brucite $\left(\mathrm{Mg}(\mathrm{OH})_{2}\right)$.

${ }^{29}$ Si MAS NMR spectra are shown in Figure 9 and the deconvolution following the procedure outlined in $[11,15,17]$ is given in Table 6. The presence of $\mathrm{MgO}$ and the increase of $\mathrm{pH}$ (see below) results in shorter silicate chains in the $\mathrm{C}-\mathrm{S}-\mathrm{H}$ as visible in the higher amount of the $\mathrm{Q}^{1}$ tetrahedra site attributed to $\mathrm{C}-\mathrm{S}-\mathrm{H}$ at $-79.6 \mathrm{ppm}$. This is in accordance with [17], where a shortening of the silicate chains of pure $\mathrm{C}-\mathrm{S}-\mathrm{H}$ has been observed when the $\mathrm{pH}$ is increasing. The increase of the $\mathrm{Q}^{1}$ signal points towards an increase of $\mathrm{Ca} / \mathrm{Si}$ in $\mathrm{C}-\mathrm{S}-\mathrm{H}[20,36]$, which agrees with the calculated $\mathrm{Ca} / \mathrm{Si}$ in $\mathrm{C}-\mathrm{S}-\mathrm{H}$ in Table 6. 
In contrast to the XRD and TGA data, the ${ }^{29} \mathrm{Si}$ MAS NMR data indicate clearly the formation of a small amount of M-S-H with the chemical shift between -92 and -97 ppm, characteristic of M-S-H's $Q^{3}$ tetrahedral sites, in addition of the signals characteristic of C-S-H. The quantifications based on the deconvolutions of the $Q^{3}$ bands give $9 \pm 3 \%, 14 \pm 3.5 \%$ and $19 \pm 4 \%$ of the silica (Table 6) attributed to M-S-H in the 3 samples.

The total intensity of the sites attributed to C-S-H decreases slightly but remains high: $80 \%$ of the silica is attributed to C-S-H even for the highest addition. The formation of some M-S-H is consistent with the observed increase of the $\mathrm{Ca} / \mathrm{Si}$ in the remaining $\mathrm{C}-\mathrm{S}-\mathrm{H}$ as some silica is used to form M-S-H.

The FTIR and Raman spectra (Figure 10 and Figure 11) of all samples confirm the ${ }^{29}$ Si MAS NMR results; the samples are mainly composed of C-S-H as the spectra are similar to the pure C-S-H spectra. The FTIR band (Figure 10) at $\sim 970 \mathrm{~cm}^{-1}$, characteristic of C-S-H, develops a small shoulder at $1045 \mathrm{~cm}^{-1}$ if $\mathrm{MgO}$ is added confirming the precipitation of a small amount of M-S-H as does the additional presence of a band at $870 \mathrm{~cm}^{-1}$ in the Raman spectra, characteristic of Si-O symmetrical stretching of $\mathrm{Q}^{2}$ tetrahedra site in $\mathrm{M}-\mathrm{S}-\mathrm{H}$. 


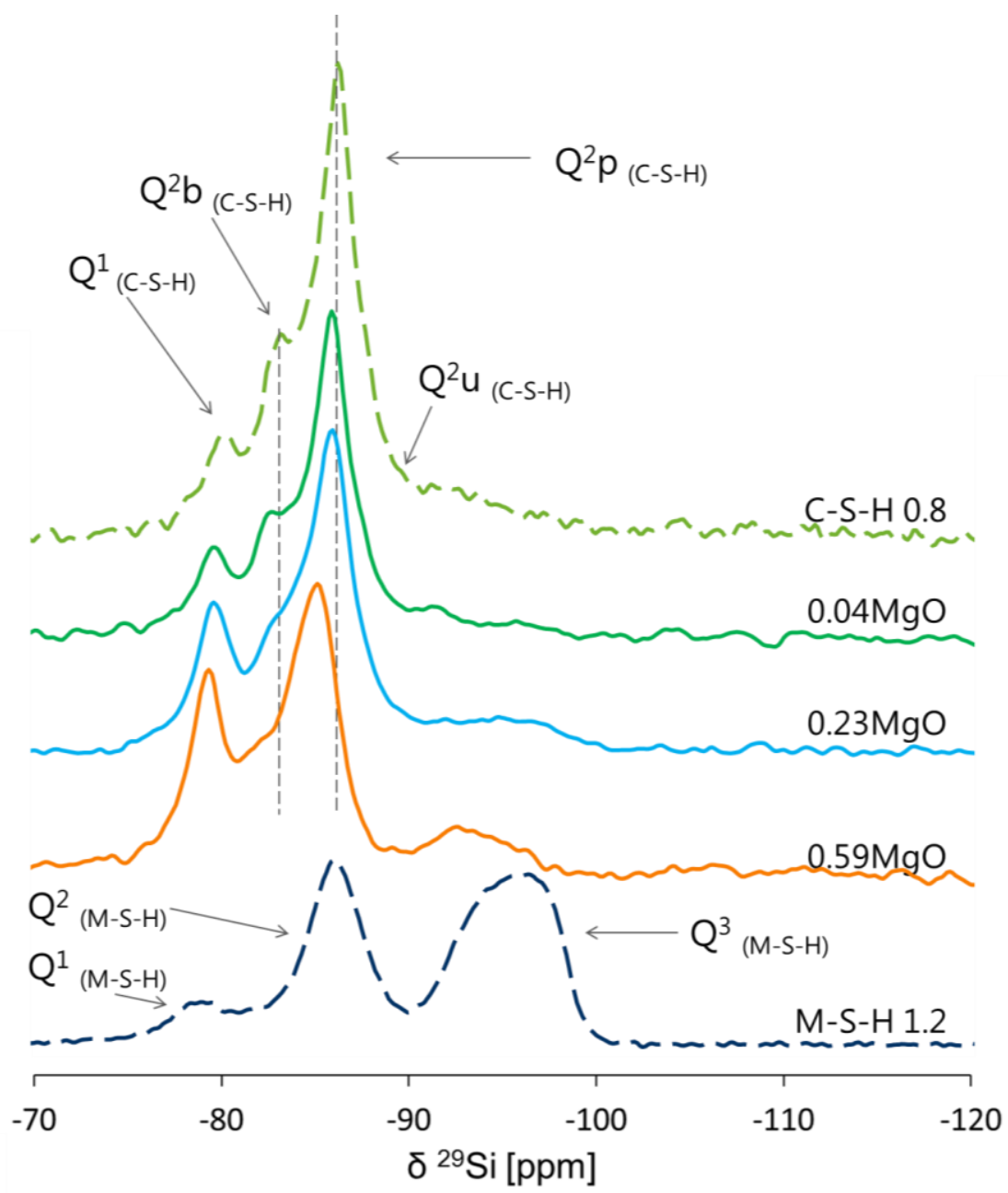

Figure 9: ${ }^{29} \mathrm{Si}$ MAS NMR spectra of C-S-H samples where $\mathrm{MgO}$ has been added: $0.04 \mathrm{MgO}, 0.23 \mathrm{MgO}$ and $0.59 \mathrm{MgO}$ after 1 year of curing at $20^{\circ} \mathrm{C}$, (C-S-H and M-S-H shown as references).

Table 6: Relative intensities (\% $\pm 2.5 \%$ ) of different silicon shifts obtained from the deconvolution of the ${ }^{29}$ Si MAS NMR spectra for the samples $0.04 \mathrm{MgO}, 0.23 \mathrm{MgO}$ and $0.59 \mathrm{MgO}$ after 1 year of curing at $20{ }^{\circ} \mathrm{C}(\mathrm{C}-\mathrm{S}$ - $\mathrm{H}$ and $\mathrm{M}$-S-H shown as references) ( $\delta^{29}$ Si in ppm $\left.\pm 0.3 \mathrm{ppm}\right)$.

\begin{tabular}{|c|c|c|c|c|c|c|c|c|c|c|c|c|c|c|c|c|}
\hline & \multicolumn{3}{|c|}{$\delta^{29} \mathrm{Si}(\mathrm{C}-\mathrm{S}-\mathrm{H})$} & \multirow[b]{2}{*}{$Q^{2} u$} & \multirow{3}{*}{$\mathrm{MCL}$} & \multirow{3}{*}{$\mathrm{Ca} / \mathrm{Si}$} & \multirow{3}{*}{$\begin{array}{c}Q^{3} \\
-93.5\end{array}$} & \multicolumn{5}{|c|}{$\delta^{29} \mathrm{Si}(\mathrm{M}-\mathrm{S}-\mathrm{H})$} & & \multirow{2}{*}{$\begin{array}{l}\text { Am. silica } \\
\mathrm{Q}^{3}\left(\mathrm{SiO}_{2}\right)\end{array}$} & \multicolumn{2}{|l|}{ Total } \\
\hline & $\mathrm{Q}^{1}$ & $Q^{2} b$ & $Q^{2} p$ & & & & & $Q^{1}$ & $Q^{2}$ & $Q^{3} a$ & $Q^{3} b$ & $Q^{3} c$ & & & C-S-H & M-S-H \\
\hline & -79.6 & -82.8 & -85.8 & -88.2 & & & & -78.3 & -85.5 & -92.7 & -94.7 & -96.7 & $Q^{2} / Q^{3}$ & -100.9 & \multicolumn{2}{|c|}{$\%$ of silica } \\
\hline C-S-H 0.8 & 8 & 22 & 59 & 7 & 25 & & 4 & - & - & - & - & - & - & - & 96 & - \\
\hline $0.04 \mathrm{MgO}$ & 14 & 20 & 51 & 5 & 13 & 0.85 & 3 & - & 4 & 3 & 0 & 2 & 0.9 & 0 & 89 & 9 \\
\hline $0.23 \mathrm{MgO}$ & 18 & 18 & 43 & 5 & 9 & 0.90 & 2 & - & 6 & 2 & 2 & 3 & 0.9 & 2 & 83 & 14 \\
\hline $0.59 \mathrm{MgO}$ & 26 & 18 & 36 & 0 & 6 & 1.00 & 1 & - & 9 & 5 & 2 & 2 & 0.9 & 0 & 80 & 19 \\
\hline M-S-H 0.8 & - & - & - & - & - & & - & 2 & 34 & 23 & 8 & 27 & 0.6 & 6 & - & 94 \\
\hline M-S-H 1.2 & - & - & - & - & - & & - & 6 & 47 & 14 & 12 & 21 & 1.0 & - & - & 100 \\
\hline
\end{tabular}


In addition, the presence of brucite $\left(\mathrm{Mg}(\mathrm{OH})_{2}\right)$ is observed by $\mathrm{XRD}$ and TGA with the characteristic reflection peaks at $18.6,32.7,38.0^{\circ}$ 2theta (Figure 7 ) and the water loss located at $400^{\circ} \mathrm{C}$ in the TGA curves (Figure 8). Brucite is also visible by FTIR with a band at $3692 \mathrm{~cm}^{-1}$ $[15,66]$ in all the samples (data not shown). The amount of brucite quantified from TGA is compiled in Table 7. This amount is lower than the theoretical maximum brucite content and corresponds to 31,41 and $74 \% \pm 20 \%$ of the total magnesium content in the different samples, confirming the presence of magnesium bound in M-S-H. Table 7 also shows the quantification of brucite by TGA in the samples cured at $50{ }^{\circ} \mathrm{C}$. In all cases, less brucite is present and more magnesium is found bound in $\mathrm{M}-\mathrm{S}-\mathrm{H}$ at $50^{\circ} \mathrm{C}$ than at $20^{\circ} \mathrm{C}$. This difference is related to the very slow reaction kinetics of brucite dissolution and $\mathrm{M}-\mathrm{S}-\mathrm{H}$ formation at $20{ }^{\circ} \mathrm{C}$, while the reaction kinetics are faster at higher temperature, as discussed in more detail in [11].

Table 7: Theoretical maximum amount of brucite calculated from total amount of magnesium added, experimental measured brucite content, and magnesium distribution between brucite and $M-S-H$.

\begin{tabular}{cccc|ccc}
\hline Temperature & & $20^{\circ} \mathrm{C}$ & \multicolumn{3}{c}{$50^{\circ} \mathrm{C}$} \\
$\mathrm{Mg} / \mathrm{Si}$ & 0.04 & 0.23 & 0.59 & 0.04 & 0.23 & 14 \\
\hline Theo. $\mathrm{max} \mathrm{Mg}(\mathrm{OH})_{2}{ }^{\mathrm{a}}(\mathrm{g} / 100 \mathrm{~g})$ & 3.9 & 17.1 & 30.3 & 2.9 & 33 \\
Exp. $\mathrm{Mg}(\mathrm{OH})_{2}{ }^{b}(\mathrm{~g} / 100 \mathrm{~g})$ & 1.2 & 7 & 22.5 & 0.8 & 3.5 & 19.2 \\
\hline \% of $\mathrm{Mg}$ in brucite & 31 & 41 & 74 & 28 & 58 \\
\% of Mg in M-S-H & 69 & 59 & 26 & 72 & 75 & 42 \\
$\mathrm{Mg}$ in M-S-H (mmol) & 0.5 & 2.7 & 2.9 & 0.4 & 2.9 & 5.6 \\
\hline
\end{tabular}

${ }^{a}$ Theo. max \% of $\mathrm{Mg}(\mathrm{OH})_{2}$ is the amount of brucite formed based on the initial amount of MgO added considering the total mass of solid, the initial $\mathrm{MgO}$ is obtained by dissolution

${ }^{b}$ calculated from TGA

The presence of only a small quantity of M-S-H is observed by FTIR, Raman and ${ }^{29}$ Si MAS NMR for C-S-H if $\mathrm{MgO}$ is added, while 30 to $70 \%$ of magnesium is present as brucite. 


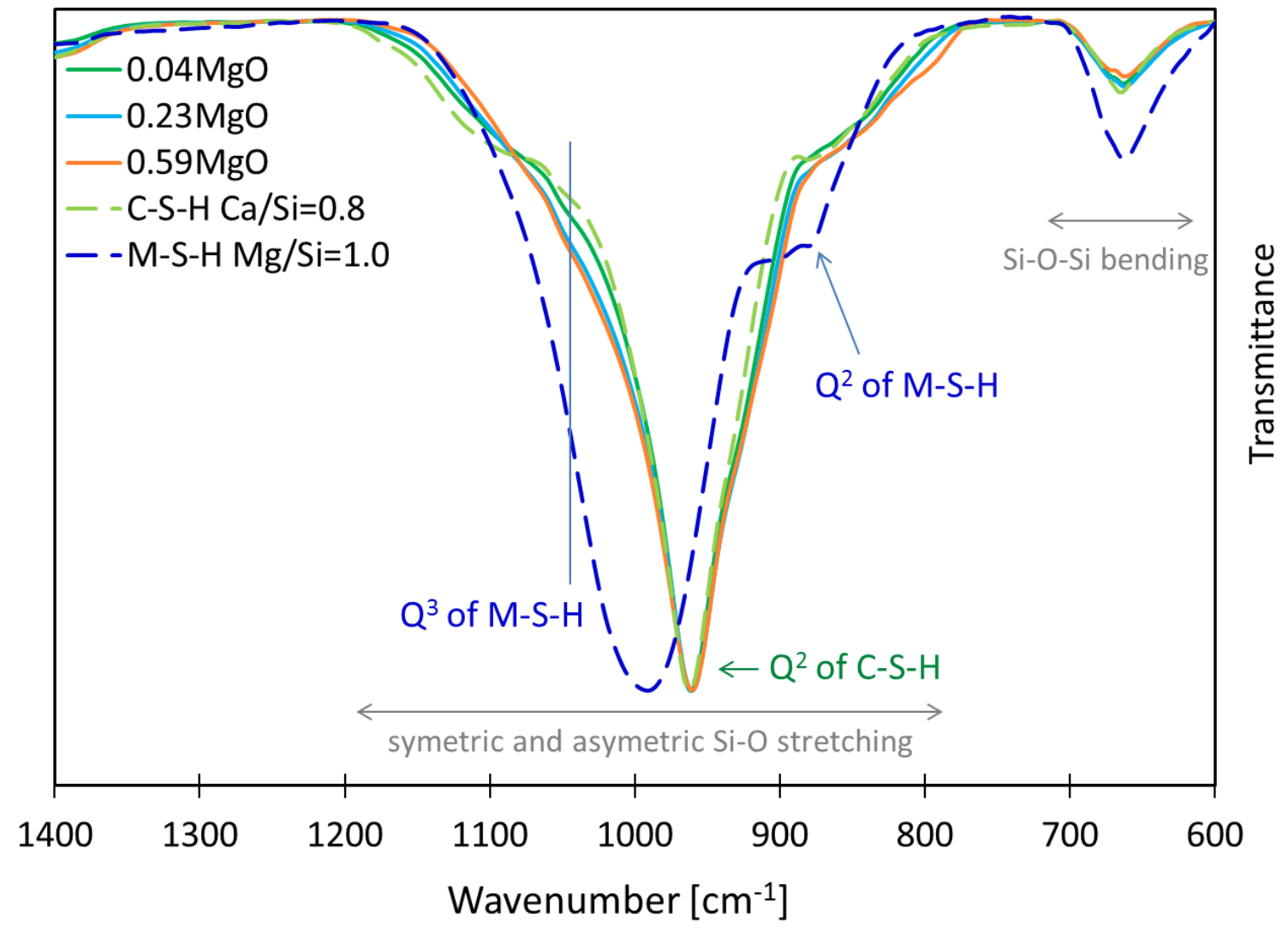

Figure 10: FTIR spectra of C-S-H samples where $\mathrm{MgO}$ has been added: $C-S-H+0.04 \mathrm{MgO}, C-S-H+0.23 \mathrm{MgO}$ and $\mathrm{C}-\mathrm{S}-\mathrm{H}+0.59 \mathrm{MgO}$ after 1 year of curing at $20^{\circ} \mathrm{C}$, spectra of $\mathrm{M}-\mathrm{S}-\mathrm{H} 0.8$ and $\mathrm{C}-\mathrm{S}-\mathrm{H} 0.8$ shown as references (the vertical line indicates the shoulder due to the $Q^{3}$ silicate sites in $\left.M-S-H\right)$. 


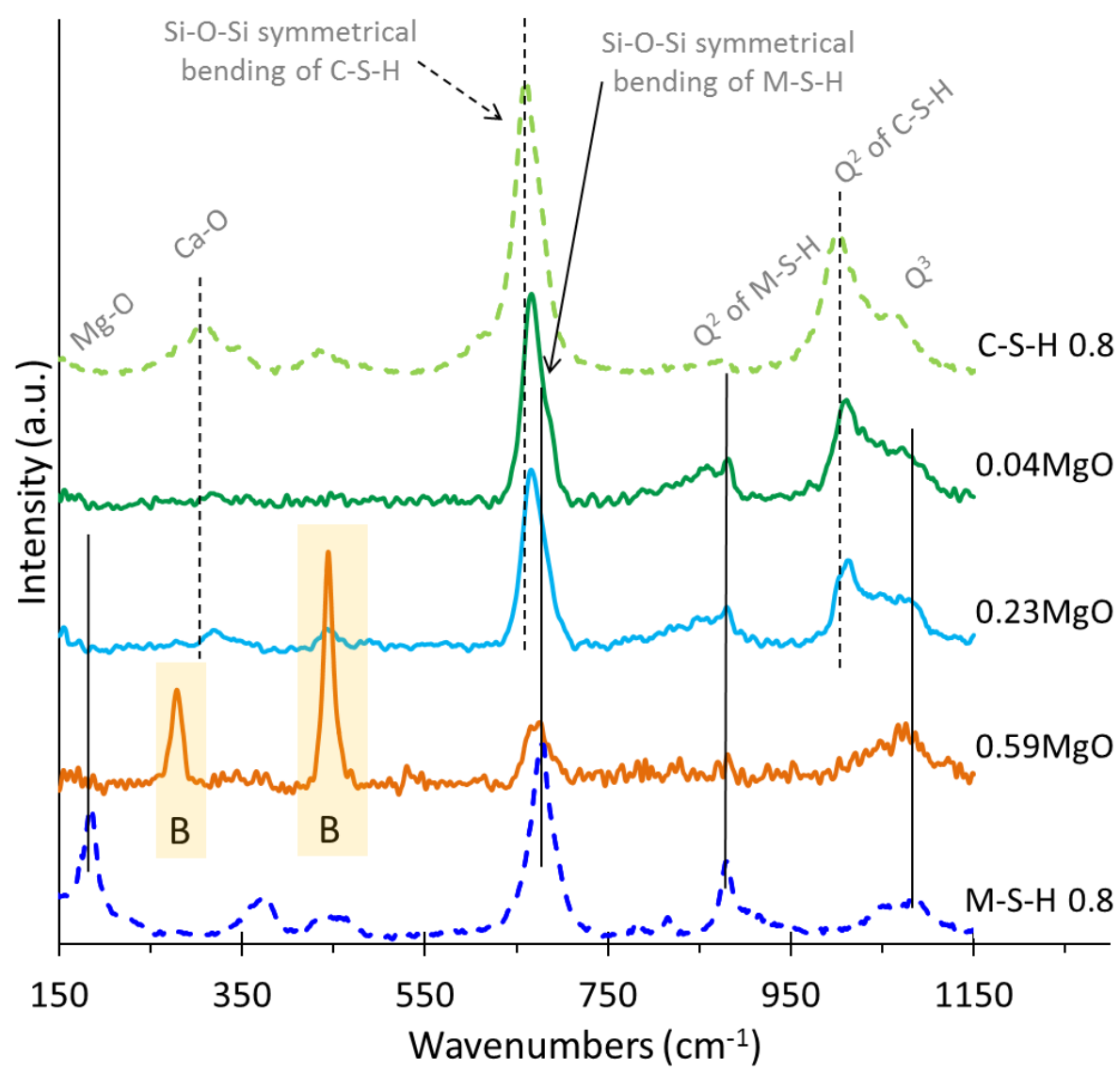

Figure 11: Raman spectra of $C-S-H$ samples where $M g O$ has been added: $C-S-H+0.04 M g O, C-S-H+0.23 M g O$ and $\mathrm{C}-\mathrm{S}-\mathrm{H}+0.59 \mathrm{MgO}$ after 1 year of curing at $20^{\circ} \mathrm{C}$, (C-S-H and $\mathrm{M}-\mathrm{S}-\mathrm{H}$ shown as references), B=brucite $\left(\mathrm{Mg}(\mathrm{OH})_{2}\right)$.

The experimentally determined $\mathrm{Mg} / \mathrm{Si}$ and $\mathrm{Ca} / \mathrm{Si}$ in $\mathrm{M}-\mathrm{S}-\mathrm{H}$ and $\mathrm{C}-\mathrm{S}-\mathrm{H}$ have been calculated from the quantification of the brucite by TGA (Table 7), the quantification of the silica attributed to C-S-H or M-S-H ( ${ }^{29} \mathrm{Si}$ MAS NMR, Table 6) and taking into account the dissolved ions in solution and are summarized in Table 8 . The increase of $\mathrm{Ca} / \mathrm{Si}$ in the $\mathrm{C}-\mathrm{S}-\mathrm{H}$ corresponds to the experimental observations with the decrease of MCL in $\mathrm{C}-\mathrm{S}-\mathrm{H} . \mathrm{A} \mathrm{Mg} / \mathrm{Si}$ of $\approx 0.9$ is observed. However, the data derived from mass balance calculations are associated with a high experimental error. 
Table 8: Initial composition of the samples $\mathrm{C}-\mathrm{S}-\mathrm{H}+0.04 \mathrm{MgO}, \mathrm{C}-\mathrm{S}-\mathrm{H}+0.23 \mathrm{MgO}$ and $\mathrm{C}-\mathrm{S}-\mathrm{H}+0.59 \mathrm{MgO}$ in mmol, amount of $\mathrm{Ca}$, Si and $\mathrm{Mg}$ attributed to the solution at equilibrium, \% of silica attributed to $M-S-H$ and $C-S-H$, experimental \% of magnesium attributed to $M-S-H$, and experimentally determined $M g / S i$ and $C a / S i$ in $M-S-H$ and $C-S-H$.

\begin{tabular}{|c|c|c|c|c|c|c|c|c|c|c|c|}
\hline \multirow{2}{*}{$\begin{array}{l}\text { initial } \\
\mathrm{Mg} / \mathrm{Si}\end{array}$} & \multicolumn{3}{|c|}{$\begin{array}{l}\text { initial }^{\mathrm{a}} \\
\mathrm{mmol}\end{array}$} & \multicolumn{3}{|c|}{$\begin{array}{l}\text { liquid part (from IC) } \\
\text { mmol }\end{array}$} & \multicolumn{2}{|c|}{$\begin{array}{c}\text { \% Si (NMR) } \\
\text { in }\end{array}$} & \multirow{2}{*}{$\begin{array}{c}\% \mathrm{Mg}(\mathrm{TGA}) \\
\text { in } \\
\mathrm{M}-\mathrm{S}-\mathrm{H} \\
\end{array}$} & \multirow[t]{2}{*}{$\mathrm{Mg} / \mathrm{Si}$} & \multirow[t]{2}{*}{$\mathrm{Ca} / \mathrm{Si}$} \\
\hline & $\mathrm{Ca}^{\mathrm{a}}$ & $\mathrm{Si}^{\mathrm{a}}$ & $\mathrm{Mg}^{\mathrm{a}}$ & $\mathrm{Ca}$ & $\mathrm{Si}$ & $\mathrm{Mg}$ & M-S-H & C-S-H & & & \\
\hline 0.04 & 15.2 & 19.1 & 0.7 & 0.1 & 0.2 & $\sim 0^{b}$ & 9 & 89 & 69 & - & $0.9 \pm 0.1$ \\
\hline 0.23 & 15.2 & 19.1 & 4.5 & 0.1 & 0.1 & $\sim 0^{b}$ & 15 & 84 & 59 & $0.9 \pm 0.5$ & $1.0 \pm 0.1$ \\
\hline 0.59 & 15.2 & 19.1 & 11.2 & 0.3 & $\sim 0^{b}$ & $\sim 0^{b}$ & 19 & 77 & 26 & $0.8 \pm 0.5$ & $1.0 \pm 0.1$ \\
\hline
\end{tabular}

a from Table 1,

${ }^{b}$ detected by IC (cf. Table 4) but $\leq 0.01 \mathrm{mmol}$ and not taking account in the calculations

The addition of $\mathrm{MgO}$ to pure water leads to the formation of brucite and a $\mathrm{pH}$ value of 10.5 . Interestingly, the addition of $\mathrm{MgO}$ to $\mathrm{C}-\mathrm{S}-\mathrm{H}$ increases the $\mathrm{pH}$ well above the $\mathrm{pH} 10.5$ observed for pure $\mathrm{C}-\mathrm{S}-\mathrm{H}(\mathrm{Ca} / \mathrm{Si}=0.8)($ Table 4$)$ and the solutions are clearly undersaturated with respect to brucite (Figure 6). This increase in $\mathrm{pH}$ and hydroxide concentrations is related to the release of calcium from $\mathrm{C}-\mathrm{S}-\mathrm{H}$ at higher $\mathrm{Ca} / \mathrm{Si}$ as visible in the increased calcium concentrations (Table 4 and Figure 6). While the calcium and hydroxide concentrations increase, the silicon concentrations are lowered (Figure 6) in agreement with the changes expected for pure C-S-H phase if the $\mathrm{Ca} / \mathrm{Si}$ of $\mathrm{C}-\mathrm{S}-\mathrm{H}$ is increased from 0.8 to $1.0[17,20,22]$. This confirms that the addition of $\mathrm{MgO}$ to $\mathrm{C}-\mathrm{S}-\mathrm{H}$ leads to the formation of $\mathrm{C}-\mathrm{S}-\mathrm{H}$ with a higher $\mathrm{Ca} / \mathrm{Si}$ as indicated in Table 8 in agreement with the higher fraction of $\mathrm{Q}^{1}$ silicate tetrahedra which has been observed by ${ }^{29} \mathrm{Si}$ MAS NMR. The magnesium concentrations remain clearly below the solubility of brucite as shown in Figure 6, although brucite is still present. This is due to the very slow dissolution of brucite when silicon and M-S-H are present, as discussed in details in [11].

Comparable calcium and silicon concentrations have been measured after 3 months and 1 year, while the magnesium concentrations decrease with time. At $50^{\circ} \mathrm{C}$, similar concentrations were measured as at $20^{\circ} \mathrm{C}$ as detailed in Table 4 , in agreement with the observations in pure M-S-H 
[11] and in pure C-S-H $[67,68]$. However, less brucite is present at $50^{\circ} \mathrm{C}$ where the dissolution of brucite, even in the presence of silicon, proceeds faster than at $20^{\circ} \mathrm{C}$ as in pure $\mathrm{M}-\mathrm{S}-\mathrm{H}$ [11].

\section{Comparison with thermodynamic modelling}

The measured calcium, magnesium and silicon concentrations and the solubility curves calculated by GEMS [41] at $20^{\circ} \mathrm{C}$ are plotted as a function of $\mathrm{pH}$ in Figure 6 . The results of thermodynamic modelling, using the thermodynamic data for C-S-H and M-S-H as detailed in Table 2, show in general a good agreement with the changes observed. The modelling predicts the formation of C-S-H and M-S-H for $\mathrm{pH}$ values between 9.6 and 12. At lower $\mathrm{pH}$ values (7.8 to 9.6) only M-S-H is predicted. Figure 12 shows that the calculated $\mathrm{Mg} / \mathrm{Si}$ and $\mathrm{Ca} / \mathrm{Si}$ decrease if $\mathrm{MgCl}_{2}$ is added to the C-S-H and increase if $\mathrm{MgO}$ is added to C-S-H. The trends compare well with the experimentally determined $\mathrm{Mg} / \mathrm{Si}$ and $\mathrm{Ca} / \mathrm{Si}$ from mass balance (Table 6 \& Table 9) except the $\mathrm{Mg} / \mathrm{Si}$ at $\mathrm{pH}$ values above 10.5 . The $\mathrm{Ca} / \mathrm{Si}$ in $\mathrm{C}-\mathrm{S}-\mathrm{H}$ estimated from the $\mathrm{MCL}$ (Table 3 \& Table 6) shows in all cases comparable trends.

The $\mathrm{MgCl}_{2}$ additions lower the $\mathrm{pH}$ values from above 10 to 8 as the magnesium precipitates as M-S-H while the chloride ions remain in solution. The addition of low quantities of $\mathrm{MgCl}_{2}$ led to formation of M-S-H while the $\mathrm{Ca} / \mathrm{Si}$ in $\mathrm{C}-\mathrm{S}-\mathrm{H}$ is lowered. Higher additions lowered the $\mathrm{pH}$ below 9.5 which resulted in the destabilization of C-S-H as shown in Figure 12. The modelled decrease of both $\mathrm{Ca} / \mathrm{Si}$ and $\mathrm{Mg} / \mathrm{Si}$ in the $\mathrm{C}-\mathrm{S}-\mathrm{H}$ and $\mathrm{M}-\mathrm{S}-\mathrm{H}$ is in the same range as the experimentally determined atomic ratios (Table 5, Figure 12).

Also the modelled effect of $\mathrm{MgO}$ addition to C-S-H (Figure 6 and Figure 12) fits well to the measured calcium and silicon concentrations and to the increase of the $\mathrm{Ca} / \mathrm{Si}$ (Table 8 and Figure 12) in $\mathrm{C}-\mathrm{S}-\mathrm{H}$. The formation of $\mathrm{M}-\mathrm{S}-\mathrm{H}$ is predicted, which agrees with the very low magnesium 
concentrations. No brucite formation is predicted up to $\mathrm{pH} 12$, although brucite has been observed experimentally. The strong under saturation of the solution with respect to brucite visible in Figure 6 indicates a kinetic hindrance of brucite dissolution in the presence of dissolved silicon, which has been observed also in M-S-H systems if brucite is present $[9,10,12]$, which can be explained by the partial reaction of brucite. It can be expected that, after longer reaction times or higher temperature, higher $\mathrm{Mg} / \mathrm{Si}$ would be reached as indicated by the presence of less brucite at $50{ }^{\circ} \mathrm{C}$.

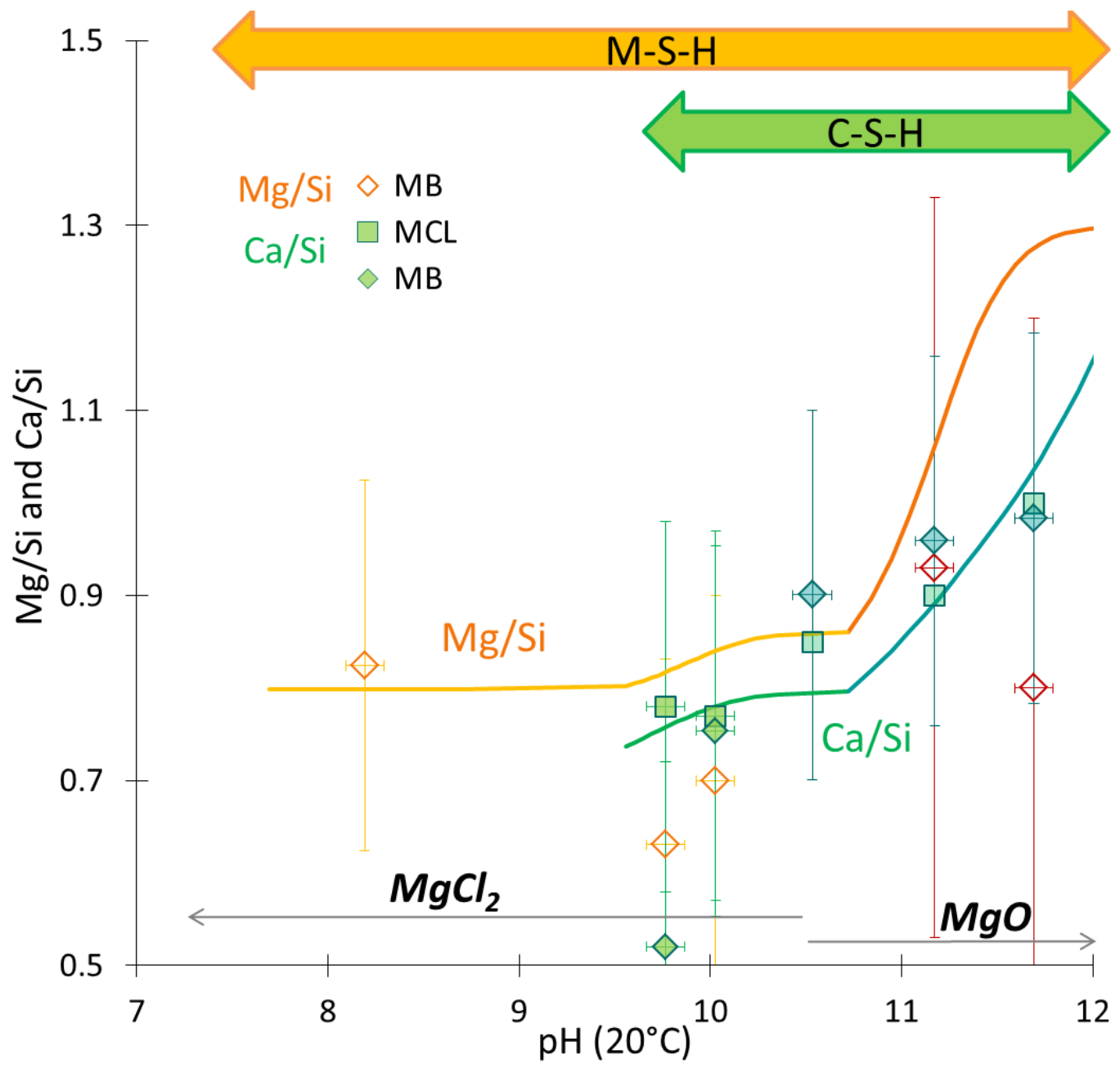

Figure 12: Evolution of atomic ratios calculated by GEMS and comparison with the ratios obtained experimentally (from MCL ( ${ }^{29}$ Si MAS NMR, Table 3 \& Table 7), and from MB, mass balance (Table 5 \& Table 8)). 


\section{Conclusions}

It has been observed experimentally that low $\mathrm{Ca} / \mathrm{Si} \mathrm{C}-\mathrm{S}-\mathrm{H}$ is stable in the $\mathrm{pH}$ range 9.6 to 11.5. Lowering the $\mathrm{pH}$ due to the addition of low quantities of $\mathrm{MgCl}_{2}$ leads to a decrease of the $\mathrm{Ca} / \mathrm{Si}$ in C-S-H and to the formation of M-S-H. At pH values below 9.6, C-S-H is destabilized while M-S-H remains stable down to $\mathrm{pH}$ values $~ 7.5$. The M-S-H formed from the dissolution of C-S-H and $\mathrm{MgCl}_{2}$ is comparable to $\mathrm{M}-\mathrm{S}-\mathrm{H}$ prepared from $\mathrm{MgO}$ and $\mathrm{SiO}_{2}[10,11,13,15]$.

Increasing the $\mathrm{pH}$ values from 10 to 11.5 by the addition of $\mathrm{MgO}$ leads to an increase of the $\mathrm{Ca} / \mathrm{Si}$ ratio in C-S-H, i.e. to shorter silicate chains, higher calcium concentrations and lower silicon concentrations. M-S-H formation is observed up to a $\mathrm{pH}$ of 11.5. Experimentally, the persistence of some brucite is observed as the dissolution of brucite is very slow in the presence of silicon while modelling predicts only the presence of $\mathrm{M}-\mathrm{S}-\mathrm{H}$ which is thermodynamically more stable. It is shown that $\mathrm{M}-\mathrm{S}-\mathrm{H}$ is stable in the $\mathrm{pH}$ range 7.5 to 12 . A small incorporation of calcium in $\mathrm{M}$ S-H seems possible, although it could not be proven and further investigations are needed.

The present paper has demonstrated that C-S-H can be destabilized in the presence of magnesium in the $\mathrm{pH}$ range 7.5 to 12 . The destabilization is fast at $\mathrm{pH}$ values below 10 and proceeds very slowly at $\mathrm{pH}$ values above 10 . This fast kinetic at lower $\mathrm{pH}$ values might explain why M-S-H has been observed clearly after 2 and 5 years at the interface between clays and "low pH cements", where $\mathrm{pH}$ values ranges from 10 to 12 [4-6], but not at the interface between clays and Portland cements [1-3], where $\mathrm{pH}$ values above 13 are present [69]. In the long-term, however, M-S-H could be expected to form also at the interface with Portland cement, as M-S-H has been observed in both Portland cement and in blended concretes exposed for long times to seawater, which also contains significant quantities of magnesium [70]. 


\section{Acknowledgements}

The authors would like to thank Céline Cau-Dit-Coumes, Emilie L'Hôpital and Daniel Rentsch for helpful discussions and to Luigi Brunetti and Beatrice Fischer for support in the preparation of the samples and analysis. The NMR hardware was partially granted by the Swiss National Science Foundation (SNFS, grant no. 150638).

\section{References}

[1] A. Jenni, U. Mäder, C. Lerouge, S. Gaboreau, B. Schwyn, In situ interaction between different concretes and Opalinus clay, Physics and Chemistry of the Earth, Parts A/B/C, 70 (2014) 71-83.

[2] A. Dauzeres, P. Le Bescop, P. Sardini, C. Cau Dit Coumes, Physico-chemical investigation of clayey/cement-based materials interaction in the context of geological waste disposal: Experimental approach and results, Cement and Concrete Research, 40 (2010) 1327-1340.

[3] U. Mäder, A. Jenni, C. Lerouge, S. Gaboreau, S. Miyoshi, Y. Kimura, V. Cloet, M. Fukaya, F. Claret, T. Otake, M. Shibata, B. Lothenbach, 5-year chemicophysical evolution of concrete-claystone interfaces, Swiss Journal of Geosciences, accepted (2017).

[4] M. Codina, C. Cau-dit-Coumes, P. Le Bescop, J. Verdier, J. Ollivier, Design and characterization of low-heat and low-alkalinity cements, Cement and Concrete Research, 38 (2008) 437-448.

[5] B. Lothenbach, G. Le Saout, M. Ben Haha, R. Figi, E. Wieland, Hydration of a low-alkali CEM III/B-SiO2 cement (LAC), Cement and Concrete Research, 42 (2012) 410-423.

[6] B. Lothenbach, D. Rentsch, E. Wieland, Hydration of a silica fume blended low-alkali shotcrete cement, Physics and Chemistry of the Earth, Parts A/B/C, 70 (2014) 3-16.

[7] A. Dauzères, G. Achiedo, D. Nied, E. Bernard, S. Alahrache, B. Lothenbach, Magnesium perturbation in low-pH concretes placed in clayey environmentsolid characterizations and modeling, Cement and Concrete Research, 79 (2016) 137-150.

[8] J.L. Garcia Calvo, A. Hidalgo, C. Alonso, L. Fernández Luco, Development of low-pH cementitious materials for HLRW repositories: Resistance against 
ground waters aggression, Cement and Concrete Research, 40 (2010) 12901297.

[9] Z. Li, T. Zhang, J. Hu, Y. Tang, Y. Niu, J. Wei, Q. Yu, Characterization of reaction products and reaction process of $\mathrm{MgO}-\mathrm{SiO}_{2}-\mathrm{H}_{2} \mathrm{O}$ system at room temperature, Construction and Building Materials, 61 (2014) 252.

[10] J. Szczerba, R. Prorok, E. Śnieżek, D. Madej, K. Maślona, Influence of time and temperature on ageing and phases synthesis in the $\mathrm{MgO}-\mathrm{SiO}_{2}-\mathrm{H}_{2} \mathrm{O}$ system, Thermochimica Acta, 567 (2013) 57-64.

[11] E. Bernard, B. Lothenbach, D. Rentsch, I. Pochard, A. Dauzères, Formation of magnesium silicate hydrates (M-S-H), Physics and Chemistry of the Earth, Parts A/B/C, (2017).

[12] T. Zhang, C. Cheeseman, L. Vandeperre, Development of low pH cement systems forming magnesium silicate hydrate (MSH), Cement and Concrete Research, 41 (2011) 439-442.

[13] D.R.M. Brew, F.P. Glasser, Synthesis and characterisation of magnesium silicate hydrate gels, Cement and Concrete Research, 35 (2005) 85-98.

[14] J. Wei, Q. Yu, W. Zhang, H. Zhang, Reaction products of MgO and microsilica cementitious materials at different temperatures, Journal of Wuhan University of Technology-Mater. Sci. Ed., 26 (2011) 745-748.

[15] D. Nied, K. Enemark-Rasmussen, E. L'Hopital, J. Skibsted, B. Lothenbach, Properties of magnesium silicate hydrates (MSH), Cement and Concrete Research, 79 (2016) 323-332.

[16] C. Roosz, S. Grangeon, P. Blanc, V. Montouillout, B. Lothenbach, P. Henocq, E. Giffaut, P. Vieillard, S. Gaboreau, Crystal structure of magnesium silicate hydrates (MSH): The relation with 2: $1 \mathrm{Mg}-\mathrm{Si}$ phyllosilicates, Cement and Concrete Research, 73 (2015) 228-237.

[17] E. L'Hopital, B. Lothenbach, D. Kulik, K. Scrivener, Influence of calcium to silica ratio on aluminium uptake in calcium silicate hydrate, Cement and Concrete Research, 85 (2016) 111-121.

[18] T. Bach, E. Chabas, I. Pochard, C. Cau Dit Coumes, J. Haas, F. Frizon, A. Nonat, Retention of alkali ions by hydrated low-pH cements: Mechanism and $\mathrm{Na}^{+} / \mathrm{K}^{+}$selectivity, Cement and Concrete Research, 51 (2013) 14-21.

[19] J. Haas, A. Nonat, From C-S-H to C-A-S-H: Experimental study and thermodynamic modelling, Cement and Concrete Research, 68 (2015) 124138.

[20] B. Lothenbach, A. Nonat, Calcium silicate hydrates: Solid and liquid phase composition, Cement and Concrete Research, 78 (2015) 57-70.

[21] S.-Y. Hong, F. Glasser, Alkali binding in cement pastes: Part I. The CSH phase, Cement and Concrete Research, 29 (1999) 1893-1903. 
[22] C.S. Walker, S. Sutou, C. Oda, M. Mihara, A. Honda, Calcium silicate hydrate (CSH) gel solubility data and a discrete solid phase model at $25^{\circ} \mathrm{C}$ based on two binary non-ideal solid solutions, Cement and Concrete Research, 79 (2016) 1-30.

[23] G. Renaudin, J. Russias, F. Leroux, C. Cau-dit-Coumes, F. Frizon, Structural characterization of $\mathrm{C}-\mathrm{S}-\mathrm{H}$ and $\mathrm{C}-\mathrm{A}-\mathrm{S}-\mathrm{H}$ samples-Part II: Local environment investigated by spectroscopic analyses, Journal of Solid State Chemistry, 182 (2009) 3320-3329.

[24] I.G. Richardson, The calcium silicate hydrates, Cement and Concrete Research, 38 (2008) 137-158.

[25] X. Cong, R.J. Kirkpatrick, ${ }^{29}$ Si MAS NMR study of the structure of calcium silicate hydrate, Advanced Cement Based Materials, 3 (1996) 144-156.

[26] I. Klur, B. Pollet, J. Virlet, A. Nonat, CSH structure evolution with calcium content by multinuclear NMR, Nuclear magnetic resonance spectroscopy of cement-based materials, Springer1998, pp. 119-141.

[27] J.-B. d'Espinose de Lacaillerie, M. Kermarec, O. Clause, ${ }^{29} \mathrm{Si}$ NMR observation of an amorphous magnesium silicate formed during impregnation of silica with $\mathrm{Mg}$ (II) in aqueous solution, The Journal of Physical Chemistry, 99(47) (1995) 17273-17281.

[28] S.A. Walling, H. Kinoshita, S.A. Bernal, N.C. Collier, J.L. Provis, Structure and properties of binder gels formed in the system $\mathrm{Mg}(\mathrm{OH})_{2}-\mathrm{SiO}_{2}-\mathrm{H}_{2} \mathrm{O}$ for immobilisation of Magnox sludge, Dalton Transactions, 44 (2015) 8126-8137. [29] G. Qian, G. Xu, H. Li, A. Li, Mg-xonotlite and its coexisting phases, Cement and Concrete Research, 27 (1997) 315-320.

[30] S. Diamond, W.L. Dolch, J.L. White, Studies on Tobermorite-Like Calcium Silicate Hydrates, Technical Paper, Purdue University Lafayette Indiana, No. 33 (1963).

[31] Z. Pytel, J. Malolepszy, DTA studies of phases synthesized in the system CaO-MgO- $\mathrm{SiO}_{2}-\mathrm{H}_{2} \mathrm{O}$, Silicates industriels, 65 (2000) 81-85.

[32] S. Komarneni, E. Breval, D.M. Roy, R. Roy, Reactions of some calcium silicates with metal cations, Cement and Concrete Research, 18 (1988) 204220.

[33] O. Shrivastava, S. Komarneni, E. Breval, $\mathrm{Mg}^{2+}$ uptake by synthetic tobermorite and xonotlite, Cement and Concrete Research, 21 (1991) 83-90.

[34] T. Mitsuda, Paragenesis of $11 \AA$ tobermorite and poorly crystalline hydrated magnesium silicate, Cement and Concrete Research, 3 (1973) 71-80. [35] B. Lothenbach, D. Nied, E. L'Hôpital, G. Achiedo, A. Dauzères, Magnesium and calcium silicate hydrates, Cement and Concrete Research, 77 (2015) 6068. 
[36] E. L'Hôpital, B. Lothenbach, G. Le Saout, D. Kulik, K. Scrivener, Incorporation of aluminium in calcium-silicate-hydrates, Cement and Concrete Research, 75 (2015) 91-103.

[37] B. Lothenbach, P. Durdzinski, K. DeWeerdt, Thermogravimetric analysis, in: K. Scrivener, R. Snellings, B. Lothenbach (Eds.) A Practical Guide to Microstructural Analysis of Cementitious Materials, CRC Press, Oxford, UK, 2016, pp. 177-212.

[38] F. Deschner, F. Winnefeld, B. Lothenbach, S. Seufert, P. Schwesig, S. Dittrich, F. Goetz-Neunhoeffer, J. Neubauer, Hydration of Portland cement with high replacement by siliceous fly ash, Cement and Concrete Research, 42 (2012) 1389-1400.

[39] D. Massiot, F. Fayon, M. Capron, I. King, S. Le Calvé, B. Alonso, J.O. Durand, B. Bujoli, Z. Gan, G. Hoatson, Modelling one-and two-dimensional solid-state NMR spectra, Magnetic Resonance in Chemistry, 40 (2002) 70-76.

[40] R.J. Myers, E. L'Hôpital, J.L. Provis, B. Lothenbach, Effect of temperature and aluminium on calcium (alumino)silicate hydrate chemistry under equilibrium conditions. , Cement and Concrete Research, 68 (2015) 83-93.

[41] D. Kulik, T. Wagner, S.V. Dmytrieva, G. Kosakowski, F. Hingerl, K.V. Chudnenko, U. Berner, GEM-Selektor geochemical modeling package: revised algorithm and GEMS3K numerical kernel for coupled simulation codes, Computational Geochemistry, 17 (2013) 1-24.

[42] T. Thoenen, W. Hummel, U. Berner, E. Curti, The PSI/Nagra Chemical Thermodynamic Database 12/07, PSI report 14-04, Villigen PSI, Switzerland, (2014).

[43] D.A. Kulik, Improving the structural consistency of CSH solid solution thermodynamic models, Cement and Concrete Research, 41 (2011) 477-495.

[44] E. Bernard, C. Cau-dit-Coumes, I. Pochard, A. Dauzères, B. Lothenbach, Magnesium silicate hydrate (M-S-H) compared to phyllosilicate minerals, in preparation.

[45] C. Roosz, S. Gaboreau, S. Grangeon, D. Prêt, V. Montouillout, N. Maubec, S. Ory, P. Blanc, P. Vieillard, P. Henocq, Distribution of water in synthetic calcium silicate hydrates, Langmuir, 32 (2016) 6794-6805.

[46] F. Jin, A. Al-Tabbaa, Thermogravimetric study on the hydration of reactive magnesia and silica mixture at room temperature, Thermochimica Acta, 566 (2013) 162-168.

[47] A.J. Allen, J.J. Thomas, H.M. Jennings, Composition and density of nanoscale calcium-silicate-hydrate in cement, Nature materials, 6 (2007) 311316. 
[48] L. Skinner, S. Chae, C. Benmore, H. Wenk, P. Monteiro, Nanostructure of calcium silicate hydrates in cements, Physical review letters, 104 (2010) 195502.

[49] J. Haas, Etude expérimentale et modélisation thermodynamique du système $\mathrm{CaO}-\mathrm{SiO}_{2}-\left(\mathrm{Al}_{2} \mathrm{O}_{3}\right)-\mathrm{H}_{2} \mathrm{O}$, Université de Bourgogne, 2012.

[50] P. Yu, R.J. Kirkpatrick, B. Poe, P.F. McMillan, X. Cong, Structure of calcium silicate hydrate (C-S-H): Near-, Mid-, and Far-infrared spectroscopy, Journal of the American Ceramic Society, 82 (1999) 742-748.

[51] L. Black, C. Breen, J. Yarwood, K. Garbev, P. Stemmermann, B. Gasharova, Structural features of C-S-H (I) and its carbonation in air-a Raman spectroscopic study. Part II: carbonated phases, Journal of the American Ceramic Society, 90 (2007) 908-917.

[52] K. Garbev, P. Stemmermann, L. Black, C. Breen, J. Yarwood, B. Gasharova, Structural features of $\mathrm{C}-\mathrm{S}-\mathrm{H}$ (I) and its carbonation in air-a Raman spectroscopic study. Part I: fresh phases, Journal of the American Ceramic Society, 90 (2007) 900-907.

[53] I. Richardson, J. Skibsted, L. Black, R.J. Kirkpatrick, Characterisation of cement hydrate phases by TEM, NMR and Raman spectroscopy, Advances in Cement Research, 22 (2010) 233-248.

[54] R.J. Kirkpatrick, J. Yarger, P.F. McMillan, Y. Ping, X. Cong, Raman spectroscopy of $\mathrm{CSH}$, tobermorite, and jennite, Advanced Cement Based Materials, 5 (1997) 93-99.

[55] I. Gunnarsson, S. Arnórsson, Precipitation of poorly crystalline antigorite under hydrothermal conditions, Geochimica et Cosmochimica Acta, 69 (2005) 2813-2828.

[56] M.D. Andersen, H.J. Jakobsen, J. Skibsted, Incorporation of aluminum in the calcium silicate hydrate (CSH) of hydrated Portland cements: a high-field ${ }^{27} \mathrm{Al}$ and ${ }^{29} \mathrm{Si}$ MAS NMR investigation, Inorganic Chemistry, 42 (2003) 22802287.

[57] G. Bell, J. Bensted, F. Glasser, E. Lachowski, D. Roberts, M. Taylor, Study of calcium silicate hydrates by solid state high resolution ${ }^{29} \mathrm{Si}$ nuclear magnetic resonance, Advances in Cement Research, 3 (1990) 23-27.

[58] J.J. Chen, J.J. Thomas, H.F. Taylor, H.M. Jennings, Solubility and structure of calcium silicate hydrate, Cement and Concrete Research, 34 (2004) 14991519.

[59] I.G. Richardson, J. Skibsted, L. Black, R.J. Kirkpatrick, Characterisation of cement hydrate phases by TEM, NMR and Raman spectroscopy, Advanced Cement Based Materials, 22 (2010) 233-248. 
[60] G. Le Saout, E. Lécolier, A. Rivereau, H. Zanni, Chemical structure of cement aged at normal and elevated temperatures and pressures: Part I. Class G oilwell cement, Cement and Concrete Research, 36 (2006) 71-78.

[61] H. Sato, M. Grutzeck, Effect of starting materials on the synthesis of tobermorite, MRS Proceedings, 245, Cambridge Univ Press, 1991, pp. 235240.

[62] S.M. Leisinger, A. Bhatnagar, B. Lothenbach, C.A. Johnson, Solubility of chromate in a hydrated OPC, Applied Geochemistry, 48 (2014) 132-140.

[63] 0. Peyronnard, M. Benzaazoua, D. Blanc, P. Moszkowicz, Study of mineralogy and leaching behavior of stabilized/solidified sludge using differential acid neutralization analysis: Part I: Experimental study, Cement and Concrete Research, 39 (2009) 600-609.

[64] C. Shi, J. Stegemann, Acid corrosion resistance of different cementing materials, Cement and Concrete Research, 30 (2000) 803-808.

[65] S. Swanton, T. Heath, A. Clacher, Leaching behaviour of low Ca: Si ratio CaO-SiO 2-H 20 systems, Cement and Concrete Research, 88 (2016) 82-95.

[66] R.L. Frost, J.T. Kloprogge, Infrared emission spectroscopic study of brucite, Spectrochimica Acta Part A: Molecular and Biomolecular Spectroscopy, 55 (1999) 2195-2205.

[67] R. Barbarulo, Comportement des matériaux cimentaires: actions des sulfates et de la température, Université Laval Québec, 2002.

[68] B. Lothenbach, T. Matschei, G. Möschner, F.P. Glasser, Thermodynamic modelling of the effect of temperature on the hydration and porosity of Portland cement, Cement and Concrete Research, 38 (2008) 1-18.

[69] A. Vollpracht, B. Lothenbach, R. Snellings, J. Haufe, The pore solution of blended cements: a review, Materials and Structures, (2015) 1-27.

[70] U.H. Jakobsen, K. De Weerdt, M.R. Geiker, Elemental zonation in marine concrete, Cement and Concrete Research, 85 (2016) 12-27. 